\title{
System Design and Analysis for Conceptual Design of Oxygen-Based PC Boiler
}

\author{
Topical Report \\ April 2003 - May 2003 \\ Zhen Fan \\ Andrew Seltzer \\ November 2003 \\ DE-FC26-03NT41736
}

Task 2

Foster Wheeler Power Group, Inc.

12 Peach Tree Hill Road

Livingston, New Jersey 07039 


\section{DISCLAIMER}

This report was prepared as an account of work sponsored by an agency of the United States Government. Neither the United States Government nor any agency thereof, nor any of their employees, makes any warranty, express or implied, or assumes any legal liability or responsibility for the accuracy, completeness, or usefulness of any information, apparatus, product, or process disclosed, or represents that its use would not infringe privately owned rights. Reference herein to any specific commercial product, process, or service by trade name, trademark, manufacturer, or otherwise does not necessarily constitute or imply its endorsement, recommendation, or favoring by the United States Government or any agency thereof. The views and opinions of authors expressed herein do not necessarily state or reflect those of the United States Government or any agency thereof. 


\section{ABSTRACT}

The objective of the system design and analysis task of the Conceptual Design of Oxygen-Based PC Boiler study is to optimize the PC boiler plant by maximizing system efficiency. Simulations of the oxygen-fired plant with $\mathrm{CO}_{2}$ sequestration were conducted using Aspen Plus and were compared to a reference air-fired $460 \mathrm{Mw}$ plant. Flue gas recycle is used in the $\mathrm{O}_{2}$-fired $\mathrm{PC}$ to control the flame temperature. Parametric runs were made to determine the effect of flame temperature on system efficiency and required waterwall material and thickness. The degree of improvement on system efficiency of various modifications including hot gas recycle, purge gas recycle, flue gas feedwater recuperation, and recycle purge gas expansion were investigated. The selected $\mathrm{O}_{2}$-fired design case has a system efficiency of $30.1 \%$ compared to the air-fired system efficiency of $36.7 \%$. The design $\mathrm{O}_{2}$-fired case requires $\mathrm{T} 91$ waterwall material and has a waterwall surface area of only $44 \%$ of the air-fired reference case. Compared to other $\mathrm{CO}_{2}$ sequestration technologies, the $\mathrm{O}_{2}$-fired $\mathrm{PC}$ is substantially better than both natural gas combined cycles and post $\mathrm{CO}_{2}$ removal PCs and is slightly better than integrated gasification combined cycles. 


\section{Table of Contents}

\begin{tabular}{|c|c|c|}
\hline $\mathrm{AD}$ & 1 & \\
\hline 1.0 & Introduction & \\
\hline 2.0 & Executive Summary. & \\
\hline 3.0 & Experimental & \\
\hline 4.0 & Results and Discussion. & \\
\hline 4.1 & Reference Site and Fuel Conditions.. & \\
\hline 4.2 & Air-Fired Reference Case .... & 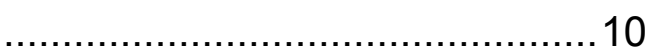 \\
\hline 4.3 & Oxygen-Based PC Plant.. & .11 \\
\hline & 3.1 $\quad$ Boiler Plant Modifications & \\
\hline & Air Separation Unit .. & 12 \\
\hline 4.4 & Parametric Cases. & 13 \\
\hline 4.5 & Hot Recycle. & \\
\hline 4.6 & $\mathrm{CO}_{2}$ Compression. & 15 \\
\hline 4.7 & Vent Gas Recycle. & \\
\hline 4.8 & Design Case. & \\
\hline 4.9 & Furnace Waterwall Temperature & \\
\hline 4.10 & Comparison With Post $\mathrm{CO}_{2}$ Capture.. & \\
\hline 5.0 & 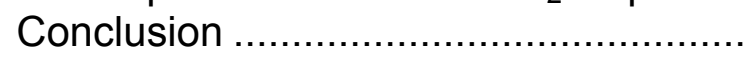 & \\
\hline 6.0 & References.. & \\
\hline 7.0 & Bibliography & \\
\hline 8.0 & of Acronv & \\
\hline
\end{tabular}




\section{LIST OF GRAPHICAL MATERIALS}

\section{Figures}

Figure 1 - Site Conditions and Coal Properties .........................................21

Figure 2 - Cycle Analysis of Case 1 (Air-Fired Reference Case) .................22

Figure 3 - Case 1 (Air-Fired Reference) Boundary Conditions and Results ......23

Figure 4 - Auxtliary Power Requirements for Case 1 .......................................24

Fgure 5 - Alr Separation Unit..........................................................25

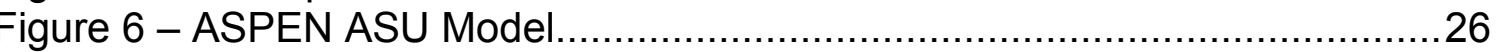

Figure 7 - Case 2 Cycle Dlagram ..........................................................27

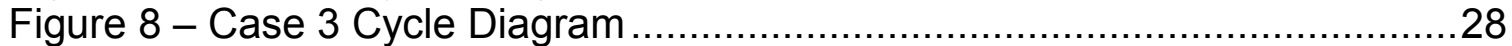

Figure 9-Case 4 Cycle Diagram ......................................................29

Flgure T0-Case 5 Cycle Dlagram .............................................................30

Flgure 71 - Case b fycle dlagram ..................................................................37

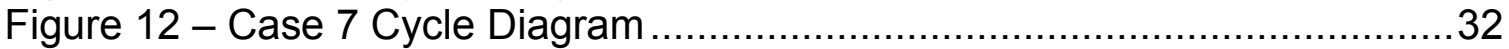

Figure 13 - Parametric Cases Summary (Without $\mathrm{CO}_{2}$ Compression)..............33 Figure 14 - Net Efflciency (without $\mathrm{CO}_{2}$ compression) Versus Flame

femperature .............................................................................

Figure 15 - ASU and AUXIlary Power Requirements versus Flame Temperature

f........................................................................................................35

Figure 16 - Recycled Gas Mass Flow Rate Versus Flame Temperature ...........36

Figure 17 - Recycled Gas Volumetric Flow Rate Versus Flame Temperature..37

Flgure 18 - Flue Gas Cooling CUrve .......................................................38

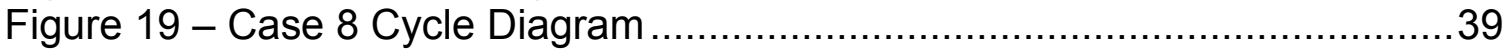

Tlgure 20 - Case g Cycle Dlagram ..............................................................40

Fígure 21 - Case 10 Cycle Diagram ........................................................41

Figure 22 - Case 11 Cycle Diagram ........................................................42

Figure 23 - Parametric Cases Summary (vith $\mathrm{CO}_{2}$ Compression) ..................43

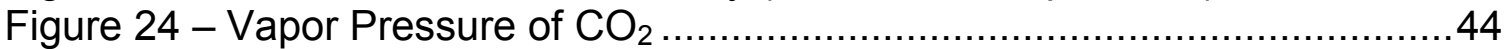

Figure 25 - Radiation Feal Fiux and Waler Waill Temperature .....................45

Figure 26 - Case 12 Cycle Diagram ......................................................46

Figure 27 - Wet End Economizer Temperature Vs. Heat Duty.........................47

Flgure 28 - Emiclency of Saved Extraction Steam versus Stage....................48

Figure 29 - Comparison of Power consumpiton of $\mathrm{CO}_{2}$ Removal of Utierent fechnologles ..........................................................................................49

Figure 30 - Comparison of Overall Cycle Effictency Point of $\mathrm{CO}_{2}$ Removal of Different Technologies...........................................................................50 


\subsection{Introduction}

This report describes the results and conclusions of Task 2, system design and analysis of the Conceptual Design of Oxygen-Based PC Boiler study. The objective of the Conceptual Design of Oxygen-Based PC Boiler study is to develop a conceptual pulverized coal (PC)-fired power plant, which facilitates the practical capture of carbon dioxide capture for subsequent sequestration. The system design and analysis task, which was performed using the Aspen Plus computer program, is aimed at optimizing the PC boiler plant operating parameters to minimize the overall power plant heat rate. The flow rates and other properties of individual streams of the power plant were calculated as the results of the Aspen Plus simulations. The required performance characteristics of such operating components as pulverized coal-fired furnace, heat recovery area, flue gas recuperator, and economizer were determined.

Two plant configurations were simulated: 1) a conventional air-fired PC power plant and 2) the proposed oxygen-based PC plant. In order to compare the performance of the oxygen-based plant with that of the conventional plant, the power output of the steam turbine in the both plants was kept constant. 


\subsection{Executive Summary}

The objective of the Conceptual Design of Oxygen-Based PC Boiler study is to develop a conceptual pulverized coal-fired power plant, which facilitates the practical capture of carbon dioxide capture for subsequent sequestration. The system design and analysis task, which was performed using the Aspen Plus computer program, is aimed at optimizing the PC boiler plant operating parameters to minimize the overall power plant heat rate.

The reference plant applied is a subcritical pressure, natural circulation boiler firing high-volatile bituminous coal generating $460 \mathrm{MWe}$. A conventional air-fired case was simulated as the comparison basis. The air-fired plant has a boiler efficiency of $88.2 \%$ and a net plant efficiency of $36.7 \%$.

The oxygen-based plant model contains all the components in the conventional plant (with the exception of the FGD) model plus the addition of an air separation unit and a flue gas cooler. Flue gas is recycled is to control the flame temperature inside the PC-fired boiler to minimize NOx formation, minimize ash slagging in the furnace combustion zone, and avoid the application of exotic materials.

Parametric runs were made varying the amount of recycled flue gas (which directly affects the flame temperature) while maintaining the same boiler outlet $\mathrm{O}_{2}$ concentration as the air-fired case. The results show that by reducing the recycled flue gas flow rate by $33 \%$, the flame temperature increases from $3574^{\circ} \mathrm{F}$ to $4337^{\circ} \mathrm{F}$, increasing the system efficiency (without $\mathrm{CO}_{2}$ compression) from $31.2 \%$ to $31.9 \%$. The system efficiency was further increased to $32.1 \%$ by raising the temperature of the recycled flue gas from $96^{\circ} \mathrm{F}$ to $148^{\circ} \mathrm{F}$.

Equipment to compress and liquefy the $\mathrm{CO}_{2}$ effluent to 2000 psia and to reduce the moisture to $50 \mathrm{ppm}$ (to avoid transport pipe corrosion) was added to the system model. This equipment reduces the system efficiency of the $3574^{\circ} \mathrm{F}$ flame temperature case from $31.2 \%$ to $27.9 \%$. Recycling the residual $\mathrm{O}_{2}$ before $\mathrm{CO}_{2}$ compression increases the system efficiency with $\mathrm{CO}_{2}$ compression to $28.3 \%$. For the high temperature case $\left(3574^{\circ} \mathrm{F}\right)$ recycling of the purge gases results in a system efficiency of $29.5 \%$. A further enhancement of this high flame temperature case was simulated by adding a flue gas feedwater heater prior to $\mathrm{CO}_{2}$ separation and a turbine expander to recover power from the recycled purge gas pressure reduction. The addition of this equipment raised the system efficiency to $29.8 \%$ with a conservative $1 \%$ unburned carbon loss and an efficiency of $30.1 \%$ with negligible unburned carbon loss.

Calculations were made using the computer program, EMISS, to determine the furnace waterwall temperature and required material and tube wall thickness for the various cases run. For the air-fired reference case, the waterwalls are carbon 
steel with a 0.285 " wall thickness. For the maximum temperature $\mathrm{O}_{2}$-fired case, the maximum wall temperature is $955^{\circ} \mathrm{F}$ for which 0.24 " thick T91 material is required. Furthermore, due to the greater temperature and greater concentrations of radiating gas species, the required waterwall surface area is only $44 \%$ of the air-fired reference case.

The efficiency of carbon sequestration in oxygen-firing boilers even can rival competing gasification plants. The power consumption of $\mathrm{CO}_{2}$ removal for $\mathrm{O}_{2}$ fired PC plants is about one-third of natural gas combined cycles, about one-half of post $\mathrm{CO}_{2}$ removal $\mathrm{PCs}$ and slightly less than integrated gasification combined cycles. The reduction in power plant efficiency of $\mathrm{CO}_{2}$ removal for $\mathrm{O}_{2}$-fired $\mathrm{PC}$ plants is nearly half of either natural gas combined cycles or post $\mathrm{CO}_{2}$ removal PCs and nearly the same as integrated gasification combined cycles. And note that the $\mathrm{O}_{2}$-firing $\mathrm{PC}$ is the only technology that removes $100 \%$ of the $\mathrm{CO}_{2}$.

The oxygen-based $\mathrm{PC}$ boiler incorporates cryogenic $\mathrm{O}_{2}$ separation which can produce very pure oxygen; but it requires substantial capital and operating costs. Membrane separation of $\mathrm{O}_{2}$ has been demonstrated at small scale employing very thin membrane fibers which preferentially allow $\mathrm{O}_{2}$ to permeate, but not $\mathrm{N}_{2}$. Although the purity of $\mathrm{O}_{2}$ from membranes may not be as high as in the cryogenic separation, lower purity oxygen may be sufficient for the oxygen-based PC boiler power cycle. Membrane separation has the potential to use less power at a lower capital cost. 


\subsection{Experimental}

This work performed for this report was performed utilizing computer program simulations. No experimental equipment was used. 


\subsection{Results and Discussion}

\subsection{Reference Site and Fuel Conditions}

In December, 2000 Parsons published a study of the cost of electricity of several case studies in $\mathrm{CO}_{2}$ sequestration from a PC boiler by post capture (Ref. 1). To provide a consistent comparison with the cases analyzed in the Parsons report, the same site conditions $\left(59^{\circ} \mathrm{F}, 14.7 \mathrm{psia}, 60 \% \mathrm{RH}\right)$ and the same fuel (Illinois \#6) were used. Site Conditions and fuel properties are presented in Figure 1. Fuel HHV and LHV were estimated by a DuLong's method and the stoichiometric air ratio of $867 \mathrm{Ib}_{\text {air }} / \mathrm{lb}$ coal was calculated based on the fuel ultimate analysis.

The liquid $\mathrm{CO}_{2}$ produced from the oxygen-based $\mathrm{PC}$ power plant is not chemically pure, but can readily sequestered in geologic formations (depleted oil and gas reservoirs, unmineable coal seams, saline formations, and shale formations) or in oceans. The liquid $\mathrm{CO}_{2}$ exits the plant at 2000 psia (Parsons study used 1200 psia). The other gases in the delivered $\mathrm{CO}_{2}$ are limited to $\mathrm{H}_{2} \mathrm{O}<$ $50 \mathrm{ppm}$ (to avoid acid corrosion), and $\mathrm{Ar}+\mathrm{N}_{2}<3 \%$ (to avoid phase separation). The excess gases in $\mathrm{CO}_{2}$ stream either have to be purged or recycled. However, since $\mathrm{SO}_{2}$, as an acid gas, similar to $\mathrm{CO}_{2}$, it can be sent to pipeline directly, and as mentioned in literature, it does not need to be separated out from $\mathrm{CO}_{2}$ product. Furthermore it is also not necessary to remove the small concentration of $\mathrm{NOx}$ in the $\mathrm{CO}_{2}$ effluent since it can be sequestered along with the $\mathrm{CO}_{2}$.

\subsection{Air-Fired Reference Case}

To study the effects of $\mathrm{CO}_{2}$ removal on the performance of power plant, an airfired PC boiler was been simulated in detail as a reference case. This model was used as the base, which was then extended to include the air separation unit (ASU) and $\mathrm{CO}_{2}$ compression for $\mathrm{O}_{2}$-fired PC cases.

The reference plant employs a subcritical pressure, natural circulation boiler firing high-volatile bituminous coal producing 2400 psig steam at $1000^{\circ} \mathrm{F}$ and reheat steam at $1000^{\circ} \mathrm{F}$ to generate $460 \mathrm{MWe}$. A condenser pressure of $2.5^{\prime \prime} \mathrm{Hg}$ was applied along with seven feedwater heaters, which raise the feedwater temperature to $494^{\circ} \mathrm{F}$.

Case 1 is the reference air-fired PC boiler case and the model and results shown in Figure 2

The Aspen Plus model includes coal mills, flue gas heater, pulverized coal-fired furnace, steam generator, superheater, reheater, economizer, ash-removal unit, nitrogen oxides (NOx) selective catalytic reactor (SCR), flue gas de-sulfurization reactor (FGD), air blower, induced draft (ID) fan, feed water pump, cooling water 
pump, feed water heaters, and a single reheat steam turbine. A coal drying function has been modeled and added into mill module to result in the proper correct mill exit gas temperature. The furnace was simulated by a zero dimensional model. However, all key tube banks of the heat recovery area (HRA) were individually modeled. The furnace roof heat absorption is also simulated. The high pressure steam temperature is controlled by water spray for desuperheat. The simulation also included heat losses from boiler and HRA sides, as well as steam pipes. Some user-defined models are included to perform emission calculations. User built-in calculations have been added to determine boiler efficiency, system net efficiency, and net power. The heat carried by exhaust streams was automatically calculated by program.

For a given steam turbine output and a fuel, ASPEN PLUS iterates for to determine the feed rates of air, coal, etc., based on specified temperature approaches and excess air requirement.

The system configuration, detailed setup parameters and summary of results for the case 1 reference case are shown in Figure 2 and Figure 3. This system has a steam turbine cycle efficiency (generator power divided by heat transferred to the steam cycle) of $45.78 \%$, a boiler efficiency (heat to steam cycle divided by heat input from fuel to boiler) of $88.2 \%$, an unburned carbon loss (UBC) of $1.0 \%$, and a net plant efficiency of $36.68 \%$ (net plant heat rate of $9302 \mathrm{Btu} / \mathrm{kwh}$ ). It has a gross power as $460 \mathrm{MW}$ at generator, an auxiliary power of $42 \mathrm{MW}$, and a net power of $418 \mathrm{MW}$. Total heat input from fuel is $3890 \mathrm{MM} \mathrm{Btu} / \mathrm{hr}$.

The temperature of the flue gas exhausted to the stack is $292^{\circ} \mathrm{F}$. The flue gas exiting the boiler contains $3.0 \%$, vol., wet $\mathrm{O}_{2}$ (18\% excess air) and contains 773 $\mathrm{klb} / \mathrm{hr}(1.95 \mathrm{lb} / \mathrm{kwh})$ of $\mathrm{CO}_{2}$. This $3.0 \% \mathrm{O}_{2}$ level is kept constant for all of the $\mathrm{O}_{2-}$ fired cases. An SCR is applied to control NOx with $\mathrm{NH}_{3} / \mathrm{NOx}=1.0$, while an FGD is used to control SOx by lime solution with $\mathrm{Ca} / \mathrm{S}=1.05, \mathrm{~L} / \mathrm{G}=10$, and $85 \%$ excess air for aeration (Figure 3).

The break down of auxiliary power for case 1 is listed in Figure 4 Most of these power consumptions were simulated directly by the ASPEN module. Some required user Fortran for those processes lacking ASPEN modules, such as solids handling. The power consumption was based on stream flows and design data. Fan power consumption was simulated based on the pressure drops from both air side and gas side. The total auxiliary power consumption, including FGD, for case 1 is approximately $9.2 \%$ of the gross power.

\subsection{Oxygen-Based PC Plant}

\subsubsection{Boiler Plant Modifications}

The oxygen-based (or oxygen-fired) plant model contains essentially all the components in the conventional plant model. In addition, it also includes an air 
separation unit (ASU) and a flue gas cooler. In the $\mathrm{O}_{2}$-fired plant, the FGD is not needed because the $\mathrm{SO}_{2}$ is acid gas similar to $\mathrm{CO}_{2}$ and can thus be sent to pipeline together with the $\mathrm{CO}_{2}$. A substantial portion of the $\mathrm{SOx}$ and $\mathrm{H}_{2} \mathrm{~S}$ will be removed as the flue gas is cooled down in the $\mathrm{CO}_{2}$ cooling and compression equipment.

The steam side components remain very similar to the air-fired case with only some changes in heat bundle duties in the heat recover area (HRA).

In $\mathrm{O}_{2}$-fired cases, flue gas is recycled is to control the flame temperature inside the PC-fired boiler to minimize NOx formation, minimize ash slagging in the furnace combustion zone, and avoid the application of exotic materials.

Before the flue gas is separated into a recycled and effluent stream (to the pipeline), it is cooled to $90^{\circ} \mathrm{F}$. Since this is below the acid/moisture dew point a heat exchanger containing acid-resistant materials must be used. The recycled gas is then reheated, before the forced draft (FD) fan, by mixing it with a bypassed hot gas to avoid reaching the dew point. After the $\mathrm{O}_{2}$ from ASU plant is mixed with recycled flue gas, it is heated by the flue gas exiting the boiler in a gas-gas heat exchanger, which acts as a recuperator to improve cycle efficiency and reduce fan power requirements.

It is assumed in this study that there is no tramp air ingress through the sealed boiler.

\subsubsection{Air Separation Unit}

For an $\mathrm{O}_{2}$-fired $\mathrm{PC}, \mathrm{O}_{2}$ purity is a key parameter for system performance and economics. A high purity $\mathrm{O}_{2}$ will produce a high purity of product $\mathrm{CO}_{2}$ gas which will reduce $\mathrm{CO}_{2}$ purification and compression power. However, producing high purity $\mathrm{O}_{2}$ requires high ASU plant operational and equipment costs. Furthermore, too high $\mathrm{O}_{2}$ purity is not necessary because the fuel combustion itself will generate some gases, such as $\mathrm{N}_{2}$ and some excess $\mathrm{O}_{2}$ is required for complete combustion, in additional to $\mathrm{CO}_{2}$ as flue gas. Therefore there is a balance point to give an optimum. After literature review and some trade studies, it was determined to use a complete ASU to separate air to $\mathrm{O}_{2}$ and $\mathrm{N}_{2} / \mathrm{Ar}$, ( $\mathrm{Ar}$ is separated out from the $\mathrm{O}_{2}$ by additional column) to maintain an $\mathrm{O}_{2}$ purity between 99.0 and $99.5 \%$.

The method of air separation chosen for this study is the commercially available large-scale cryogenic air separation technique. A traditional cryogenic ASU plant, shown in Figure 5 was simplified in the simulation to include the power consumption, but without details of distillation columns and cold heat exchangers. The ASPEN simplified ASU model is shown in Figure 6, The ASPEN model does not include the air purifier, which removes moisture, hydrocarbons, $\mathrm{CO}_{2}$, and $\mathrm{NOx}$ in an adsorber and is located between the cold box 
and air compressor. Although the separated $\mathrm{N}_{2} / \mathrm{Ar}$ gases could potentially be sold as byproducts, no economic credit for this is taken in this study. No heat recovery from the ASU air compressor inter-stage coolers is included, because recovery of this low grade heat recovery is very inefficient.

Power consumption is $23.6 \mathrm{kw} / \mathrm{klb}$ air from a Ref. 1 for a $95 \% \mathrm{O}_{2}$ purity under 67 psia ASU pressure. From Ref. 2, the power increases by $4 \%$ when $\mathrm{O}_{2}$ purity is increased from $95 \%$ to $99.5 \%$. Thus, for the $\mathrm{O}_{2}$ purity of $99.5 \%$ used in this study a power consumption of $24.5 \mathrm{kw} / \mathrm{klb}$ air was applied. For a $460 \mathrm{MW}$ steam turbine generation, the ASU plant consumes about $70 \mathrm{MW}$, or $15 \%$ of generated power.

\subsection{Parametric Cases}

There are five $\mathrm{O}_{2}$-fired cases for parametric studies as follows:

1. Case 1: air fired reference case

2. Case 2: with ASU \& gas recycle, the same mass flows of air and flue gas as case 1

3. Case 3: with ASU, reduced air, the same flue gas flow and $\mathrm{O}_{2} \%$ as case 1

4. Case 4: reduced recycle gas flow, the same flame temperature and $\mathrm{O}_{2} \%$ as case 1

5. Case 5: reduced recycle gas flow, high flame temperature and the same $\mathrm{O}_{2} \%$ as case 1

6. Case 6: reduced recycle gas flow, higher flame temperature and the same $\mathrm{O}_{2} \%$ as case 1

Case 2 has the same system net excess air (exit plant $\mathrm{O}_{2}$ flow rate divided by stoichiometric $\mathrm{O}_{2}$ flow rate) as case 1 , but because of gas recycle, more $\mathrm{O}_{2}$ is carried by recycled gas back into boiler, which raised boiler excess air (boiler exit $\mathrm{O}_{2}$ flow rate divided by stoichiometric $\mathrm{O}_{2}$ flow rate) to a very high number of $69 \%$, and a very high oxygen content of flue gas of $15.3 \%$. The cycle diagram for case 2 is shown in Figure 7.

In Case 3 the air flow rate was reduced to produce a $3 \%$, vol. $\mathrm{O}_{2}$ concentration at the boiler exit (similar to case 1). This corresponds to a boiler excess of $13.5 \%$ and a net excess of $3.1 \%$. Compared to case 2 the air flow rate of case 3 was reduced by $13 \%$ from $3422 \mathrm{klb} / \mathrm{hr}$ to $2981 \mathrm{klb} / \mathrm{hr}$. $\mathrm{O}_{2}$ concentration in the boiler is $26.9 \%$, compared to $20.4 \%$ for the air-fired case, and yields a higher combustion efficiency. Flue gas flow to the sequestration plant is reduced from $927 \mathrm{klb} / \mathrm{hr}$ in case 2 to $820 \mathrm{klb} / \mathrm{hr}$ in case 3 , which results in less $\mathrm{CO}_{2}$ compression duty. Case 3 maintains the same flue gas flow rate as cases 1 and 2 . The cycle diagram for case 3 is shown in Figure 8

In cases 4 to 6 the amount of flue gas recycle was reduced to increase the $\mathrm{O}_{2}$ level in the boiler. This increase in boiler $\mathrm{O}_{2}$ creates a higher flame temperature, 
which reduces the size of the furnace and increases the overall cycle efficiency. The effect of flame temperature on cycle efficiency is shown in Figure 13 and Figure 14. Case 4 has the same flame temperature as air-fired reference case, while cases 5 and 6 have higher flame temperatures. Although there is little change in gas exhaust flow to $\mathrm{CO}_{2}$ compressor among cases 3-6 (listed as gas exit system in Figure 13, the decreasing recycle gas flow results in reduced auxiliary power consumption for both the FD and ID fans. The reduction in FD and ID fan auxiliary power requirements is presented in Figure 15 (approximately $2.5 \mathrm{MW}$ from case 3 to case 6) along with the reduction in ASU power requirements (approximately $1 \mathrm{MW}$ from case 3 to case 6 )

Figure 16 shows the relationship of flue gas flow to boiler flame temperature. Figure 17 is a similar plot to Figure 16, but it uses volumetric flow rate as the abscissa instead of mass flow rate. Both figures show the air-fired data for comparison. It can be observed that the $\mathrm{O}_{2}$-fired $\mathrm{PC}$ has a lower volume flow rate than does the air-fired PC due to the higher molecular weight of the flue gas (i.e. $\mathrm{CO}_{2}$ versus $\mathrm{N}_{2}$ ). From case 3 to case 6 the ratio of the $\mathrm{O}_{2}$-fired $\mathrm{PC}$ volume flow rate to the air-fired PC volume flow rate drops from $75 \%$ to $57 \%$, which means for a constant flue gas velocity, boiler size is reduced.

Another advantage from decreasing the quantity of recycle gas is to increase the $\mathrm{O}_{2}$ content in the boiler (from $27 \% \mathrm{v}$ to $34 \%$ by vol. from case 3 to case 6 ) which should improve the fuel combustion and reduce the required height of the furnace. This credit has not been simulated in this system study, but will be modeled in the 3-D CFD boiler simulation study (Task 4).

\subsection{Hot Recycle}

A case with hot gas recycle (case 7, Figure 12 was run to evaluate its effect on the system performance. A hot gas recycle will bring more energy back into boiler, will reduce fuel and $\mathrm{O}_{2}$ feed rates, and reduce ASU duty, but it requires more power to the fan because of the increased recycle gas volume flow.

Figure 13 shows that increasing the recycle gas temperature from $95^{\circ} \mathrm{F}$ to $148^{\circ} \mathrm{F}$ increases the boiler efficiency from $89.60 \%$ to $90.94 \%$ and net efficiency from $31.90 \%$ to $32.12 \%$. The additional fan power increase of $0.3 \mathrm{MW}$ was more than made up by a reduction in ASU power of $0.5 \mathrm{MW}$. The resultant fuel saving is approximately $0.7 \%$. The size of the gas-gas heat exchanger increases due to the reduction in LMTD (fluid temperature difference is reduced from $213^{\circ} \mathrm{F}$ to $176^{\circ} \mathrm{F}$ for the hot end, and from $104^{\circ} \mathrm{F}$ to $74^{\circ} \mathrm{F}$ for the cold end).

There is a limit to increasing the recycle gas temperature without increasing the stack gas temperature, which will reduce efficiency and increase cooling duty. One option mentioned in literature is to raise both stack gas and recycle gas temperatures, and then recover heat from stack gas to replace part of the feedwater heaters. The merits of this approach are questionable because the 
efficiency improvement will be very small from replacing the low pressure feedwater heater.

Figure 18 shows the cooling curve for flue gas cooling before compressor. Part of the heat can be recovered to preheat the condensate. If $90 \mathrm{MMBtu} / \mathrm{hr}$ of heat is recovered (exit temperature $=142^{\circ} \mathrm{F}$ ), the steam saved from extraction will generate an additional $2.2 \mathrm{MW}$, or an efficiency increase of $0.2 \%$ point. If 150 $\mathrm{MMBtu} / \mathrm{hr}$ of heat is recovered (exit temperature $=133^{\circ} \mathrm{F}$ ), the steam saved from extraction will generate an additional $3.4 \mathrm{MW}$, or an efficiency increase of $0.3 \%$ point. This potential energy savings will be further explored in Section 4.8.

\section{6 $\quad \mathrm{CO}_{2}$ Compression}

The flue gas effluent stream (mainly $\mathrm{CO}_{2}$ ) has to be compressed to the high pipeline pressure of 1200 to 2000 psia. Using case 3 as a basis, case 8 is simulated in which the $\mathrm{CO}_{2}$ sequestration equipment is added to the system and the effluent is conservatively compressed to 2000 psia. The dominant moisture in flue gas is condensed out first during flue gas cooling before the first stage compression. The condensed water contains acid gases and has to be treated before recycle or discharge.

A flue gas dry composition before the first stage $\mathrm{CO}_{2}$ compressor from case 8 is:

\begin{tabular}{lllll}
$\mathrm{CO}_{2}$ & $\mathrm{O}_{2}$ & \multicolumn{2}{c}{$\mathrm{N}_{2}+\mathrm{Ar} \mathrm{SOx}$} & $\mathrm{H}_{2} \mathrm{O}$ \\
90.9 & 2.9 & 1.3 & 1.3 & 3.6
\end{tabular}

In literature, the $\mathrm{O}_{2}$ as low as $1.3 \%$ was used. Reducing $\mathrm{O}_{2}$ content, such as from $3.0 \%$ to $2.0 \%$ by reducing excess air, would be helpful in reducing $\mathrm{CO}_{2}$ compression power, but it is judged that and oxygen content of approximately $3.0 \%$ is required for good combustion efficiency. Both $\mathrm{CO}_{2}$ and $\mathrm{SO}_{\mathrm{x}}$ are acid gases. They combine with moisture to form acid, which causes a corrosion problem along $\mathrm{CO}_{2}$ pipeline. Therefore, after the $2^{\text {nd }}$ stage, a chemical method of active dehydration with TEG (Triethyleneglycol), regarding hydrate formation and corrosion, has been applied to remove the rest of moisture out to a very low level as less than $50 \mathrm{ppm}$, where the TEG can be regenerated by heating. In the model, the TEG dehydration was simulated, but the TEG itself was not simulated.

A four-stage compression with inter-stage cooling was applied in case 8. To reduce power, an equal compression pressure ratio of approximately 3.4 was applied. The results are shown in Figure 19 and Figure 23. The effects of the addition of the ASU and the $\mathrm{CO}_{2}$ sequestration plant can be seen in Figure 23 as follows:

Efficiency $=36.7 \%$ with air (case 1 )

Efficiency $=31.2 \%$ with ASU (case 3 )

Efficiency $=27.9 \%$ with ASU \& $\mathrm{CO}_{2}$ sequestration (case 8 ) 


\subsection{Vent Gas Recycle}

Because of limitation of the other gases in $\mathrm{CO}_{2}$ pipeline (i.e., $\mathrm{H}_{2} \mathrm{O}<50 \mathrm{ppm}$ and $\mathrm{Ar}+\mathrm{N}_{2}<3 \%$ ), the excess gases have to be purged. A novel idea applied in this study is to recycle this $\mathrm{O}_{2}$-rich purge gas back to system and to reduce ASU duty and to recover power. The vent gas recycle has been simulated in case 9 (Figure 20). To effectively separate out the non- $\mathrm{CO}_{2}$ gases, the compressed $\mathrm{CO}_{2}$ stream from the $3^{\text {rd }}$ stage is cooled down to its dew point (Figure 24) and condensed out by phase separation by a strip tower (not simulated in this study). Instead of using a compressor for the $4^{\text {th }}$ stage $\mathrm{CO}_{2}$ of compression as in case 8 , a $\mathrm{CO}_{2}$ liquid pump is used in case 9 to save power and cost.

The composition of the purge gas is as follows:

$\begin{array}{llll} & \mathrm{O}_{2} & \mathrm{~N}_{2}+\text { Ar others } \\ \text { Case } 9 & 71.6 & 28.1 & 0.3\end{array}$

Although the flue gas flow discharged to $\mathrm{CO}_{2}$ plant is nearly identical for both cases 8 and 9 as shown in Figure 23 the net excess $\mathrm{O}_{2}$ reduces to near zero when vent gas recycle is applied, and consequently the air to system is reduced from 2981 to $2905 \mathrm{klb} / \mathrm{hr}$. However since the boiler is still operated at $27.5 \% \mathrm{O}_{2}$ inlet, and a $3 \% \mathrm{O}_{2}$ outlet the boiler combustion performance will not be affected.

The addition of vent gas recycle (compare case 8 to case 9 in Figure 23) increases the net efficiency from $27.9 \%$ to $28.3 \%$, increases the net power from 317.3 to $321.8 \mathrm{MW}$, and decreases the auxiliary power from 143.1 to 138.6 MW (a net 4.5 MW saving). Gas recycle will also reduce NOx in the effluent since the majority of the NOx will be separated out with the purge gas and removed by the gas adsorber in ASU plant.

Since the vent gas from the $\mathrm{CO}_{2}$ compression plant is at 920 psia and the ASU is at 67 psia, the vent gas can be sent to an expander to generate power and reduce its pressure and temperature. This power generation is not included in case 9 , but is added in a subsequent case (see Section 4.8). Furthermore, the low temperature expanded recycled gas could be used as extra coolant for the ASU distillation column. However, this energy savings has not been accounted at present time because the model does not include the details for ASU plant.

In cases 10 and 11 the amount of flue gas recycled was reduced to increase the $\mathrm{O}_{2}$ level in the boiler (similar to cases 4 to 6 ). This increase in boiler $\mathrm{O}_{2}$ creates a higher flame temperature, which reduces the size of the furnace and increases the overall cycle efficiency. The effect of flame temperature on cycle efficiency is shown in Figure 23. which demonstrates that raising the flame temperature from $3575^{\circ} \mathrm{F}$ to $4343^{\circ} \mathrm{F}$ increases the net efficiency from $28.3 \%$ to $29.5 \%$ (boiler efficiency is also increased from $88.3 \%$ to $90.8 \%$ ). Cycle diagrams for cases 10 and 11 are shown in Figure 21 and Figure 22, respectively. 


\subsection{Design Case}

Based on the results of the parametric cases, case 12 (design case) is modeled

Since all processes that capture $\mathrm{CO}_{2}$ must include some kind of wet gas cooler, due to the low temperature to which the flue gas is cooled, case 12 utilizes a wetend economizer to recover as much of this heat as practical. In case 12 a heat exchanger is added to recover the flue gas sensible energy and prior to separation into recycle and outlet streams. The heat exchanger cools the flue gas to $142^{\circ} \mathrm{F}$ and removes $90 \mathrm{MM}$ Btu/hr. This significantly increases the boiler efficiency by reducing the energy content of the flue gas effluent. The LMTD of the heat exchanger is $34^{\circ} \mathrm{F}$ and it is judged that reducing the flue gas temperature further (below $142^{\circ} \mathrm{F}$ ) could be uneconomical since the required heat exchanger would be too large. Figure 27 shows that reducing the flue gas temperature from $142^{\circ} \mathrm{F}$ to $139^{\circ} \mathrm{F}$ (increasing the heat exchanger absorption from $90 \mathrm{MM} \mathrm{Btu} / \mathrm{hr}$ to $100 \mathrm{MM} \mathrm{Btu} / \mathrm{hr}$ ) reduces the LMTD from $34^{\circ} \mathrm{F}$ to $26^{\circ} \mathrm{F}$.

Although the flue gas outlet temperature of this additional heat exchanger is nominally at the moisture condensation temperature, the presence of SOx in the flue gas raises the dew point of gas such that sulfuric acid solutions will condense below $300^{\circ} \mathrm{F}$. Consequently the heat exchanger must be constructed from acid-resistant materials.

There are two possible applications for this wet-end economizer: 1) replace the first stage FWH1 or 2) heat up a split stream from the condensate pump. The second option results in a higher thermal efficiency since it reduces the higher pressure steam extractions. This is demonstrated in Figure 28 which shows that the efficiency (work/steam thermal energy) of the steam, if it is not extracted, increases with increasing pressure (stage). Therefore the split stream method yields higher efficiency and is applied in the design case (Figure 26).

Case 12 also incorporates a turbine expander to recover power from the recycled purge gas pressure reduction. The turbine generates $0.41 \mathrm{MW}$ of power as the pressure is reduced from 925 psia to 67 psia. The expanded gas is quite cold $\left(-183^{\circ} \mathrm{F}\right)$ and could potentially be used as a coolant for distillation operation. However, since the ASU was not modeled in detail in this study no credit for this cooling effect is taken.

Figure 26 shows the cycle diagram for case 12 . The boiler efficiency is $95.3 \%$ and the overall cycle efficiency is $29.8 \%$ (Figure 23). The $4.7 \%$ losses in the boiler efficiency is comprised of $17 \%$ sensible heat, $66 \%$ latent heat $\left(\mathrm{H}_{2} \mathrm{O}\right), 14 \%$ unburned carbon, $3 \%$ radiation. Since it is likely that with $\mathrm{O}_{2}$-fired combustion and a high flame temperature, the unburned carbon loss will be nearly zero (to be confirmed in Task 4), the boiler efficiency would be $94.1 \%$ and the overall cycle efficiency would be $30.1 \%$. 


\subsection{Furnace Waterwall Temperature}

The level of radiation in the $\mathrm{O}_{2}$-fired boiler is significantly higher than an air-fired boiler due to greater concentrations of radiating gas species $\left(\mathrm{CO}_{2}\right.$ and $\left.\mathrm{H}_{2} \mathrm{O}\right)$ and higher flame temperature. Consequently, it is important to select the proper amount of recycled flue gas to limit the water wall temperature such that a reasonable waterwall material can be used.

The maximum waterwall temperature and furnace heat flux was calculated from the ASPEN results using the Foster Wheeler computer program, EMISS. The EMISS computer program calculates radiative heat flux of $\mathrm{CO}_{2}$ and $\mathrm{H}_{2} \mathrm{O}$ gases as follows:

$$
\begin{aligned}
& Q / A=\left(\frac{\varepsilon_{\text {wall }}+1}{2}\right) \sigma\left(\varepsilon_{g} T_{g}^{4}-\alpha_{g} T_{w}^{4}\right) \\
& Q / A=U_{O}\left(T_{W}-T_{f}\right)
\end{aligned}
$$

where,

$$
\begin{array}{ll}
\varepsilon & =\varepsilon_{\mathrm{CO} 2}+\varepsilon_{\mathrm{H} 2 \mathrm{O}-\Delta \varepsilon} \Delta \\
\Delta \varepsilon & =\text { Correction factor due to spectral overlap } \\
\varepsilon_{\mathrm{CO} 2} & =\text { Emissivity of } \mathrm{CO}_{2} \text { (function of temperature, mean beam length, and } \\
& \text { partial pressure of } \left.\mathrm{CO}_{2}\right) \\
\varepsilon_{\mathrm{H} 2 \mathrm{O}} & =\text { Emissivity of } \mathrm{H}_{2} \mathrm{O} \text { (function of temperature, mean beam length, and } \\
& \text { partial pressure of } \mathrm{H}_{2} \mathrm{O} \text { ) } \\
\varepsilon_{\mathrm{g}} & =\text { Emissivity of gas at gas temperature } \\
\mathrm{\alpha}_{\mathrm{g}} & =\text { Absorptivity of gas at wall temperature (equal to emissivity) } \\
\varepsilon_{\mathrm{wall}} & =\text { Tube wall emissivity (assumed to be } 0.7 \text { ) } \\
\sigma & =\text { Stefan-Boltzmann constant }=1.714 \times 10^{-9} \mathrm{Btu} / \mathrm{hr}-\mathrm{ft}^{2}-\mathrm{R}^{4} \\
\mathrm{Q} / \mathrm{A} & =\text { Heat Flux } \\
\mathrm{T}_{\mathrm{f}} & =\text { Water/Steam fluid temperature }\left({ }^{\mathrm{O}} \mathrm{R}\right) \\
\mathrm{T}_{\mathrm{g}} & =\text { Gas temperature }\left({ }^{\circ} \mathrm{R}\right) \\
\mathrm{T}_{\mathrm{w}} & =\text { Wall temperature }\left({ }^{\circ} \mathrm{R}\right) \\
\mathrm{U}_{\mathrm{o}} & =\text { Heat transfer coefficient from outside of wall to steam/water fluid }
\end{array}
$$

Figure 25 presents the calculated furnace heat flux for cases 1 to 12 . Both the maximum heat flux (based on the maximum furnace gas temperature) and the average heat flux (based on the average furnace gas temperature) are presented. Based on the maximum heat flux, the maximum water wall temperature is computed. From this maximum wall temperature and the selected material, the tube wall minimum thickness is computed using stress allowables from the ASME Boiler and Pressure Vessel Code. 
Figure 25 shows that for the air-fired reference case (case 1), the waterwalls are carbon steel with a 0.285 " wall thickness. Even though the $\mathrm{O}_{2}$-fired cases 2 and 3 have similar furnace gas temperatures than case 1 , the substantially greater concentrations of $\mathrm{CO}_{2}$ and $\mathrm{H}_{2} \mathrm{O}$ results in a radiative heat flux of approximately $50 \%$ higher. Thus, to maintain the same wall thickness requires an upgrade in the material to the T2 alloy. As the flame temperature is increased in cases 4 to 6 and cases 9 to 11, the heat flux and wall temperature increases requiring further material upgrades. For case 11 (and case 12), the maximum wall temperature is $955^{\circ} \mathrm{F}$ for which 0.24 " thick T91 material is required.

The ratio of the average furnace heat flux of the $\mathrm{O}_{2}$-fired furnace to the average furnace heat flux of the air-fired furnace is also presented in Figure 25. For case 12 this ratio is 0.44 , which means that case 12 requires only approximately $44 \%$ of the case 1 heating surface area. This can be used as a preliminary estimate of the $\mathrm{O}_{2}$-fired furnace size. Figure 25 shows that the air-fired furnace dimensions of 36 ' x 51' x 207' (D x W x H) are substantially reduced to 27' x 38' x 140' (D x W x $\mathrm{H}$ ) in case 12. Task 4 of this study will perform a detailed design of the $\mathrm{O}_{2}$-fired boiler in detail by performing a three-dimensional CFD simulation.

\subsection{Comparison With Post $\mathrm{CO}_{2}$ Capture}

$\mathrm{CO}_{2}$ cannot be free captured and sequestrated without reducing both the plant power and efficiency because of a potential energy stored in the pressurized liquid $\mathrm{CO}_{2}$. A minimum of $40 \mathrm{kw} / \mathrm{klb}_{\mathrm{CO} 2}$ additional auxiliary power is required for $\mathrm{CO}_{2}$ compression. The difference between technologies lies in the difference in power requirements of the different $\mathrm{CO}_{2}$ or $\mathrm{O}_{2}$ separation techniques.

Parsons (Ref. 11 performed some studies on $\mathrm{CO}_{2}$ removal by a post capture method for a conventional PC boiler. The plant efficiency drops from $40.5 \%$ to $28.9 \%$ for a supercritical $\left(3500 \mathrm{psia} / 1050^{\circ} \mathrm{F} / 1050^{\circ} \mathrm{F} / 1050^{\circ} \mathrm{F} / 2.0^{\prime \prime} \mathrm{Hg}\right)$ boiler, and from $42.7 \%$ to $31.0 \%$ for an ultra supercritical (5000 psia $/ 1200^{\circ} \mathrm{F} / 1200^{\circ} \mathrm{F} / 1200^{\circ} \mathrm{F} / 2.0^{\prime \prime} \mathrm{Hg}$ ) boiler. In the study presented herein, the $\mathrm{CO}_{2}$ removal using an $\mathrm{O}_{2}$-fired $\mathrm{PC}$ is used, which relies on an ASU. The efficiency drops from $36.7 \%$ (case 1 ) to $30.1 \%$ (case 12 with minimal UBC loss) for a subcritical $\left(2415 \mathrm{psia} / 1000^{\circ} \mathrm{F} / 1000^{\circ} \mathrm{F} / 2.5^{\prime \prime} \mathrm{Hg}\right)$ boiler. Since the Parsons study compressed the effluent $\mathrm{CO}_{2}$ to $1200 \mathrm{psia}$, whereas this study herein compressed the $\mathrm{CO}_{2}$ to 2000 psia, the 1200 psia pressure is used as comparison basis, which increases the case 12 efficiency to $30.2 \%$. The net efficiency drops for these cases are

$11.7 \%$ points for supercritical, post removal

$11.7 \%$ points for ultra supercritical, post removal

$6.5 \%$ point for subcritical, $\mathrm{O}_{2}$ fired

Based on the Parson's study it appears that the efficiency reduction is independent of steam cycle. However, there is a big difference between the 
efficiency reductions for post capture and $\mathrm{O}_{2}$-fired. Furthermore, the $\mathrm{O}_{2}$-fired method gives near $100 \% \mathrm{CO}_{2}$ removal, while the post capture is practically limited to about $90 \%$ (limited by a vapor-liquid equilibrium from absorptionregeneration cycle).

Another comparison basis is the $\mathrm{kw} / \mathrm{lb}_{\mathrm{cO} 2}$ removal, where the $\mathrm{kw}$ is power generation difference between cases with and without $\mathrm{CO}_{2}$ removal. Comparing the post $\mathrm{CO}_{2}$ capture to the $\mathrm{O}_{2}$-fired case:

$187 \mathrm{kwh} / \mathrm{lbCO}_{2}$ for supercritical, $90 \%$ post removal $188 \mathrm{kwh} / \mathrm{lbCO}_{2}$ for ultra supercritical, $90 \%$ post removal $93 \mathrm{kwh} / \mathrm{lbCO}_{2}$ for subcritical, $\mathrm{O}_{2}$ fired $100 \%$ removal

Again, the change in power penalty for $\mathrm{CO}_{2}$ removal appears independent of steam cycle. From above data, it is very clear that the $\mathrm{O}_{2}-\mathrm{PC}$ has advantages over the post $\mathrm{CO}_{2}$ capture.

The efficiency of carbon sequestration in oxygen-firing boilers even can rival competing gasification plants. Figure 29 compares the power consumption of adding $\mathrm{CO}_{2}$ removal equipment to various competing technologies. Figure 29 shows that the power consumption of $\mathrm{CO}_{2}$ removal for $\mathrm{O}_{2}$-fired $\mathrm{PC}$ plants is about one-third of natural gas combined cycles (NGCC), about one-half of post $\mathrm{CO}_{2}$ removal PCs and slightly less than integrated gasification combined cycles (IGCC). Figure 30 compares the reduction in power plant efficiency of adding $\mathrm{CO}_{2}$ removal equipment to various competing technologies. Figure 30|shows that the reduction in power plant efficiency of $\mathrm{CO}_{2}$ removal for $\mathrm{O}_{2}$-fired $\mathrm{PC}$ plants is nearly half of either natural gas combined cycles (NGCC) or post $\mathrm{CO}_{2}$ removal PCs and nearly the same as integrated gasification combined cycles (IGCC). And once again note that the $\mathrm{O}_{2}$-firing $\mathrm{PC}$ is the only technology that removes $100 \%$ of the $\mathrm{CO}_{2}$. 
Figure 1 - Site Conditions and Coal Properties

\begin{tabular}{|c|c|c|c|}
\hline Elevation & $\mathrm{ft}$ & 0 & \\
\hline Ambient pressure & psia & 14.70 & \\
\hline Ambient Temperature & $\mathrm{F}$ & 59.0 & \\
\hline Ambient Temperature, wet & $\mathrm{F}$ & 51.5 & \\
\hline Relative Humidity & $\%$ & 60.0 & \\
\hline $\mathrm{P}-\mathrm{H} 2 \mathrm{O}$ & psia & 0.247 & \\
\hline $\mathrm{Y}-\mathrm{H} 2 \mathrm{O}$ & $\%$, vol & 1.010 & \\
\hline Condenser Pressure & " $\mathrm{Hg}$ & 2.50 & \\
\hline Air Composition & & Dry & Wet \\
\hline N2 & $\%$, vol & 78.085 & 77.297 \\
\hline $\mathrm{O} 2$ & $\%$, vol & 20.947 & 20.735 \\
\hline $\mathrm{Ar}$ & $\%$, vol & 0.935 & 0.926 \\
\hline $\mathrm{CO} 2$ & $\%$, vol & 0.033 & 0.033 \\
\hline $\mathrm{H} 2 \mathrm{O}$ & $\%$, vol & 0.000 & 1.010 \\
\hline Total & $\%$, vol & 100.000 & 100.000 \\
\hline
\end{tabular}

\begin{tabular}{|r|c|r|}
\hline Illinois No. 6 Coal & & \\
\hline $\mathrm{C}$ & $\%$ & $63.75 \%$ \\
\hline $\mathrm{H}$ & $\%$ & $4.50 \%$ \\
\hline $\mathrm{O}$ & $\%$ & $6.88 \%$ \\
\hline $\mathrm{N}$ & $\%$ & $1.25 \%$ \\
\hline $\mathrm{Cl}$ & $\%$ & $0.29 \%$ \\
\hline $\mathrm{S}$ & $\%$ & $2.51 \%$ \\
\hline $\mathrm{Ash}$ & $\%$ & $9.70 \%$ \\
\hline $\mathrm{H} 2 \mathrm{O}$ & $\%$ & $11.12 \%$ \\
\hline Total & $\%$ & $100.00 \%$ \\
\hline & & \\
\hline LHV & Btu/lb & 11,283 \\
\hline $\mathrm{HHV}$ & $\mathrm{Btu} / \mathrm{lb}$ & 11,631 \\
\hline
\end{tabular}


Figure 2 - Cycle Analysis of Case 1 (Air-Fired Reference Case)

Case: O2-PC-01， 05/30/2003

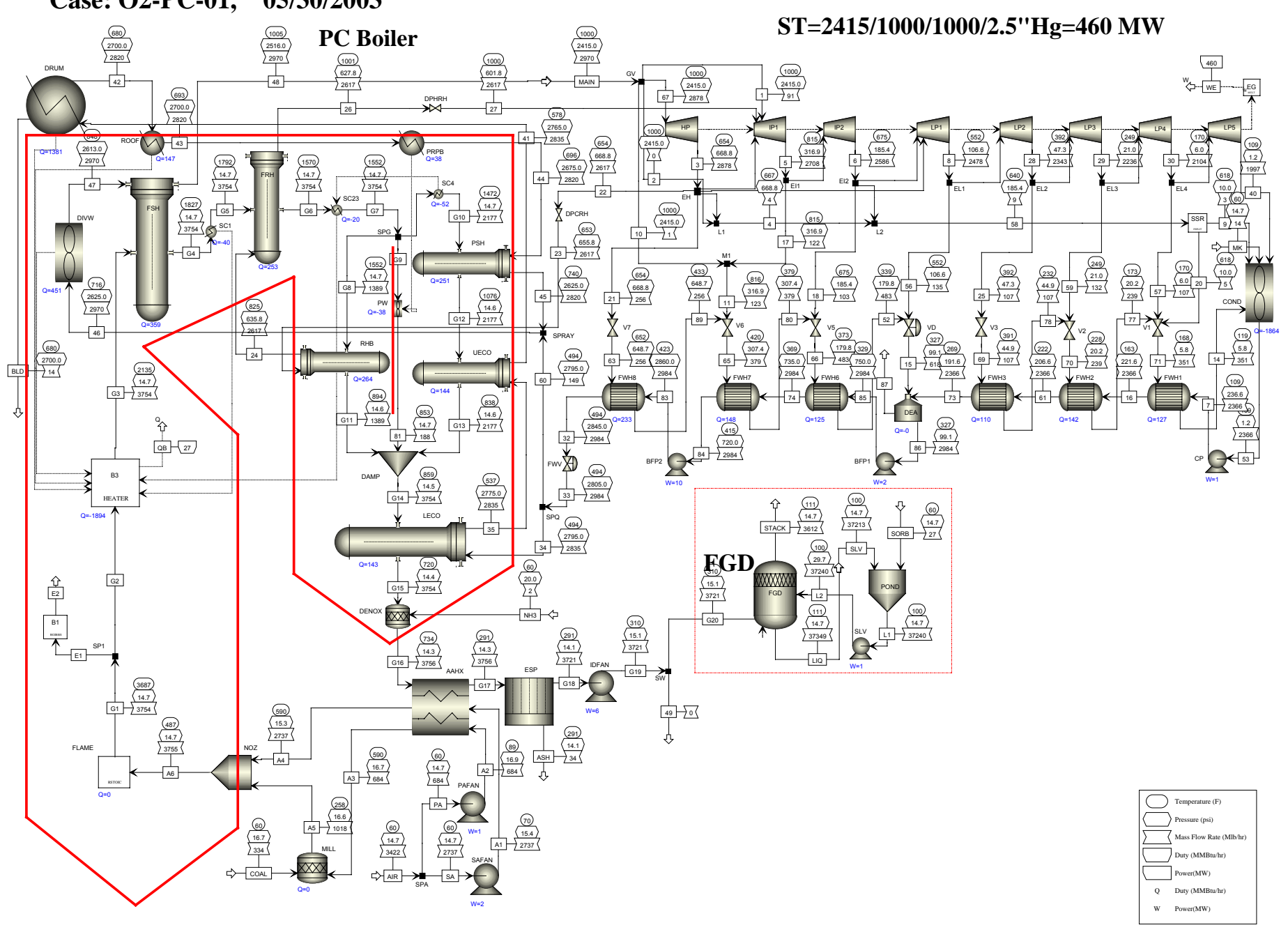


Figure 3 - Case 1 (Air-Fired Reference) Boundary Conditions and Results

\begin{tabular}{|c|c|c|c|c|c|c|c|}
\hline \multicolumn{8}{|c|}{ SETUPS \& RESULTS } \\
\hline amb & & dP-air & "H2O & ST & & result & \\
\hline elevation, $\mathrm{ft}$ & 0 & AAHX & 4.0 & main $P$, psia & 2415 & net power, MWe & 418 \\
\hline$a m b T, F$ & 60 & duct & 6.0 & main $\mathrm{T}, \mathrm{F}$ & 1000 & net eff, $\%$ & 36.68 \\
\hline amb P, psia & 14.7 & nozzle & 10.0 & RH P, psia & 602 & gross@ST, MW & 460 \\
\hline \multirow{2}{*}{$\mathrm{RH}, \%$} & 60 & sum & 20.0 & $\mathrm{RH}$ T, F & 1000 & aux power, MW & 42.1 \\
\hline & & & & FWHs & 7 & as $\%$ & 9.2 \\
\hline air & $\% v$ & dp-gas & "H2O & end wet, \% & 9.9 & & \\
\hline $\mathrm{O} 2$ & 20.74 & $\mathrm{FSH}$ & 0.5 & end $\mathrm{P}, \mathrm{Hg}$ & 2.5 & $\mathrm{HHV}$ in, mmbtu & 3890 \\
\hline $\mathrm{N} 2$ & 77.3 & $\mathrm{FRH}$ & 0.5 & & & $\mathrm{Q}$ to $\mathrm{ST}, \mathrm{mmbtu}$ & 3431 \\
\hline $\mathrm{Ar}$ & 0.93 & $\mathrm{RH}$ & 1.0 & FWH & $\mathrm{F}$ & $\mathrm{Q}$, cond, mmbtu & 1864 \\
\hline $\mathrm{CO} 2$ & 0.03 & $\mathrm{PSH}$ & 0.7 & TD & 5 & boiler eff, \% & 88.2 \\
\hline $\mathrm{H} 2 \mathrm{O}$ & 1.01 & UECO & 0.3 & DC & 10 & ST cycle eff, \% & 45.78 \\
\hline \multirow[t]{2}{*}{ sum } & 100.0 & ECO & 2.0 & FW T & 494 & Generator eff, \% & 98.3 \\
\hline & & AAHX & 1.6 & & & & \\
\hline coal & $\% w$ & Damper & 4.3 & DeSuperheat & & air, klb & 3422 \\
\hline $\mathrm{C}$ & 63.75 & $\mathrm{BHG}$ & 5.5 & $\mathrm{SH}, \%$ & 5 & coal, klb & 334 \\
\hline $\mathrm{H}$ & 4.5 & FGD & 12.0 & water $\mathrm{T}, \mathrm{F}$ & 494 & sorb, klb & 26 \\
\hline $\mathrm{O}$ & 6.88 & \multirow[t]{2}{*}{ sum } & 28.4 & \multirow[b]{2}{*}{ Boiler } & & flue gas, klb & 3721 \\
\hline $\mathrm{N}$ & 1.25 & & & & & $\mathrm{O} 2, \%$ & 3.0 \\
\hline$S$ & 2.51 & dP & "H2O & UBC, \% & 1.0 & $\mathrm{H} 2 \mathrm{O}, \%$ & 8.5 \\
\hline$A$ & 9.99 & PAFan & 60 & margin, $\%$ & 0.5 & $\mathrm{CO}, \mathrm{ppmv}$ & 71 \\
\hline $\mathrm{M}$ & 11.12 & IDFan & 28 & radiation, \% & 0.22 & NOx, ppmv & 733 \\
\hline $\mathrm{V}$ & 34.99 & SAFan & 20 & Exa, \% & 18 & SOx, ppmv & \multirow{2}{*}{$\begin{array}{r}2082 \\
42\end{array}$} \\
\hline \multirow{3}{*}{ sum } & 44.19 & & & flame $T, F$ & 3839 & after FGD & \\
\hline & 100.0 & eff & $\%$ & stack $\mathrm{T}, \mathrm{F}$ & 292 & Ash, klb & \multirow{2}{*}{$\begin{array}{r}34 \\
6.0\end{array}$} \\
\hline & & FDFan & 75 & blowdown, \% & 0.5 & $\mathrm{C}, \%$ & \\
\hline \multirow{2}{*}{$\begin{array}{l}\text { fuel HHV } \\
\text { given }\end{array}$} & $\mathrm{btu} / \mathrm{lb}$ & IDFan & 70 & miller exit $\mathrm{T}, \mathrm{F}$ & 258 & & \\
\hline & 11666 & CWPump & 80 & & & main st flow, klb & 2970 \\
\hline \multirow[t]{2}{*}{ aspen } & 11631 & BFPump & 80 & FGD \& SCR & & RH st flow, klb & 2878 \\
\hline & & Motor/mechanic & 95 & $L / G$ & 10 & end st flow, klb & 1997 \\
\hline sorb & $\% w$ & & & $\mathrm{Ca} / \mathrm{S}$ & 1.05 & & \\
\hline $\mathrm{CaCO} 3$ & 100 & air & $\%$ & Excessąir, \% & 85 & DeSOx, \% & 98 \\
\hline & & PA & 20 & $\mathrm{NH} 3 / \mathrm{NOx}$ & 1.0 & DeNOx, \% & 90 \\
\hline
\end{tabular}


Figure 4 - Auxiliary Power Requirements for Case 1

\begin{tabular}{|l|r|}
\hline Aux power & MWe \\
\hline condensed water pump & 0.6 \\
\hline LP feed water pump & 2.5 \\
\hline HP feed water pump & 9.8 \\
\hline circulating water pump & 3.9 \\
\hline FGD pump & 0.7 \\
\hline PA Fan & 1.5 \\
\hline SA Fan & 2.0 \\
\hline ID Fan & 5.6 \\
\hline FGD Fan & 4.1 \\
\hline cooling tower Fan & 2.1 \\
\hline coal handling & 2.1 \\
\hline sorb handling & 0.8 \\
\hline ash handling + ESP & 1.8 \\
\hline others (=1\%) & 4.6 \\
\hline total & 42.1 \\
\hline
\end{tabular}


Figure 5 - Air Separation Unit

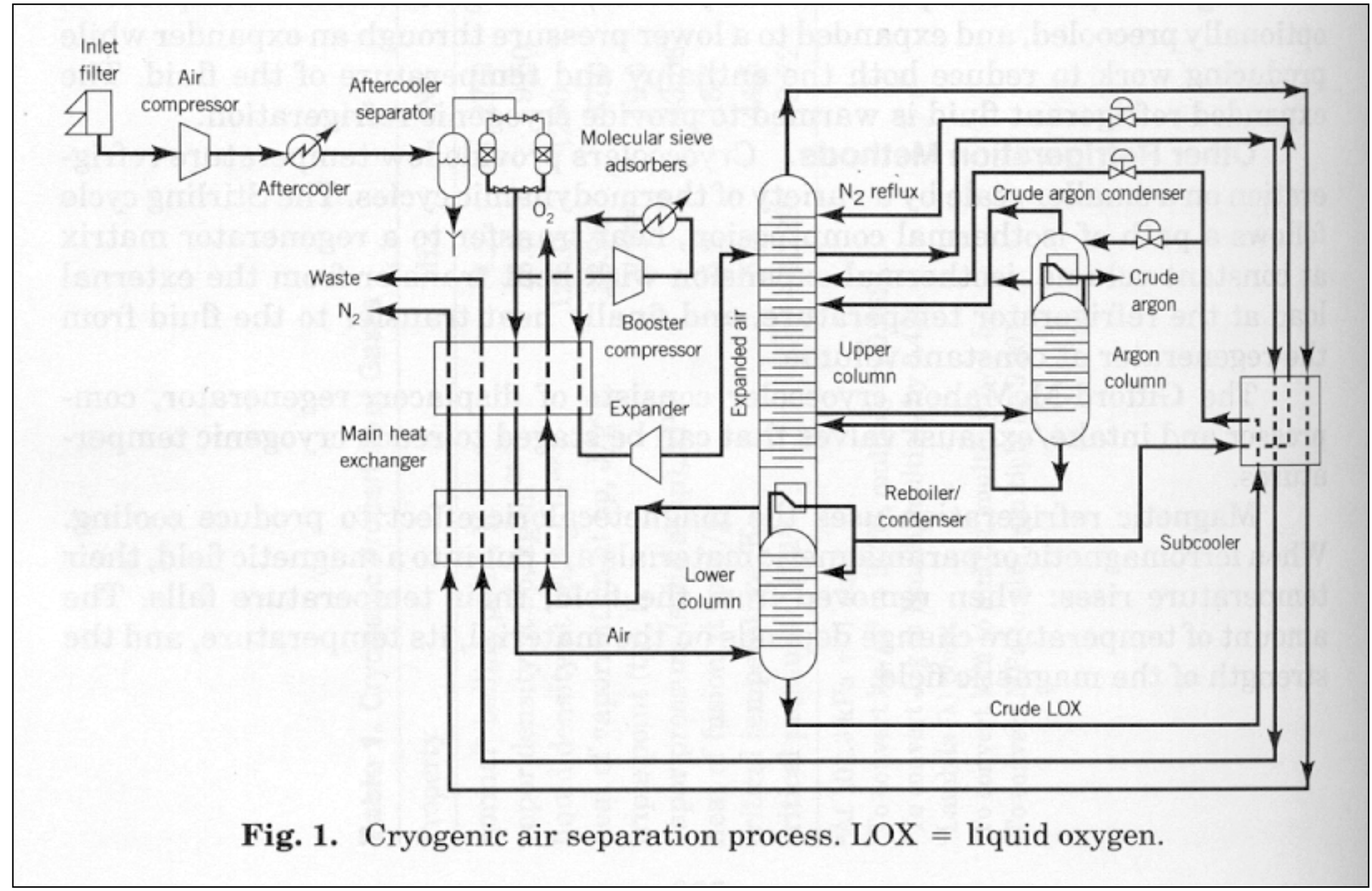


Figure 6 - ASPEN ASU Model

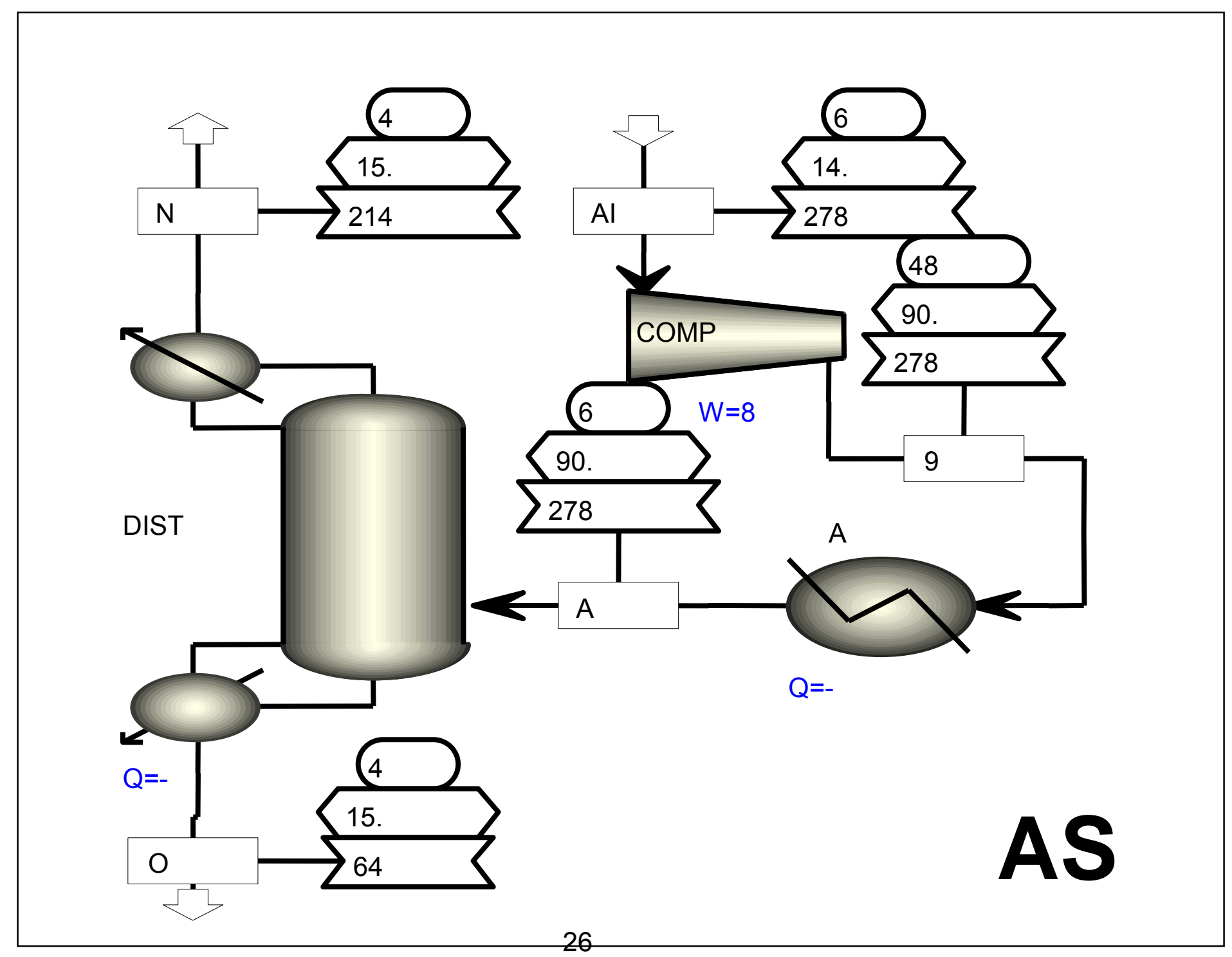




\section{Figure 7 - Case 2 Cycle Diagram}

\section{Case: Q2-PC-02, 06/05/2003}

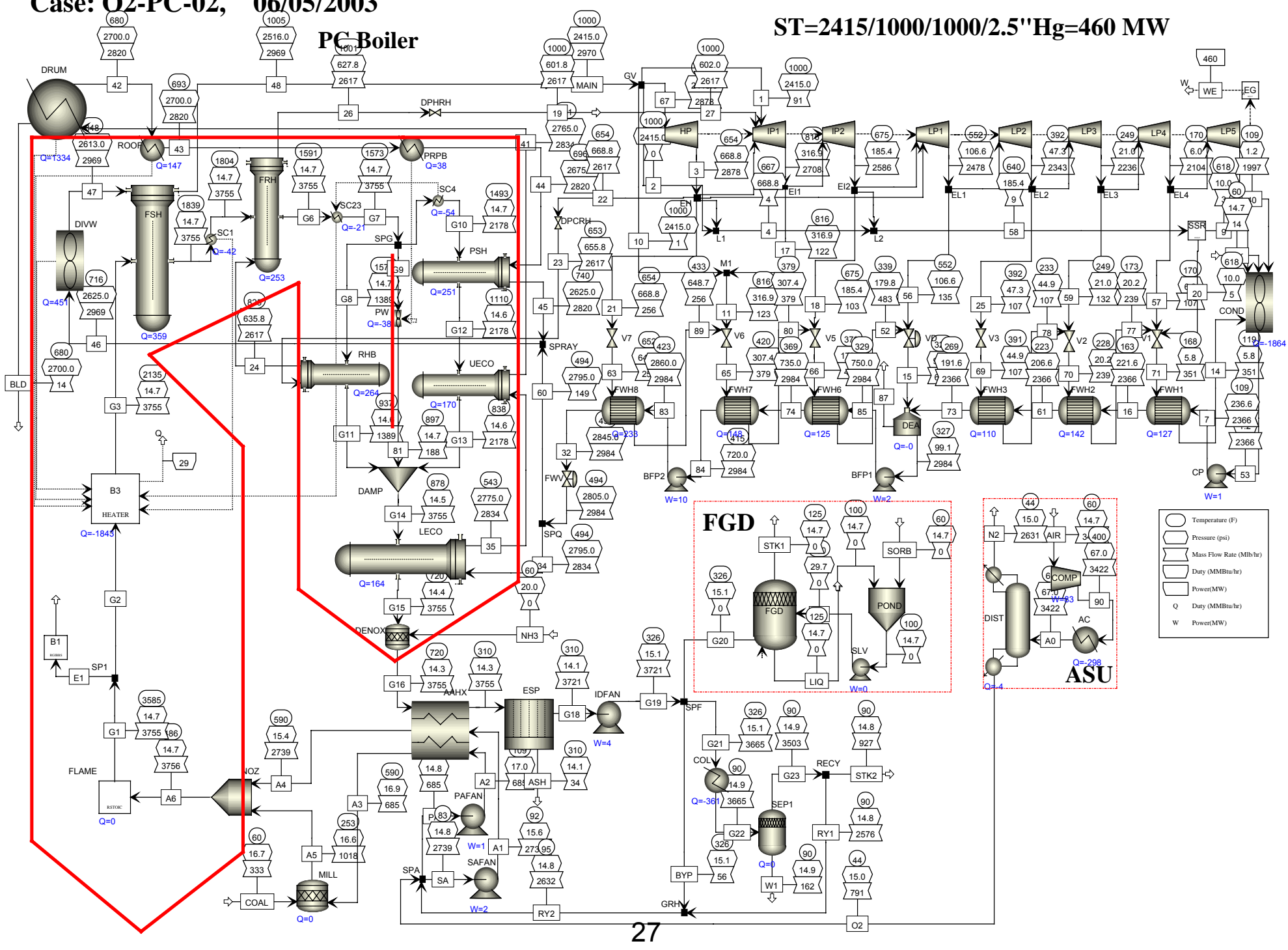




\section{Figure 8 - Case 3 Cycle Diagram}

Case: O2-PC-03， 06/05/2003

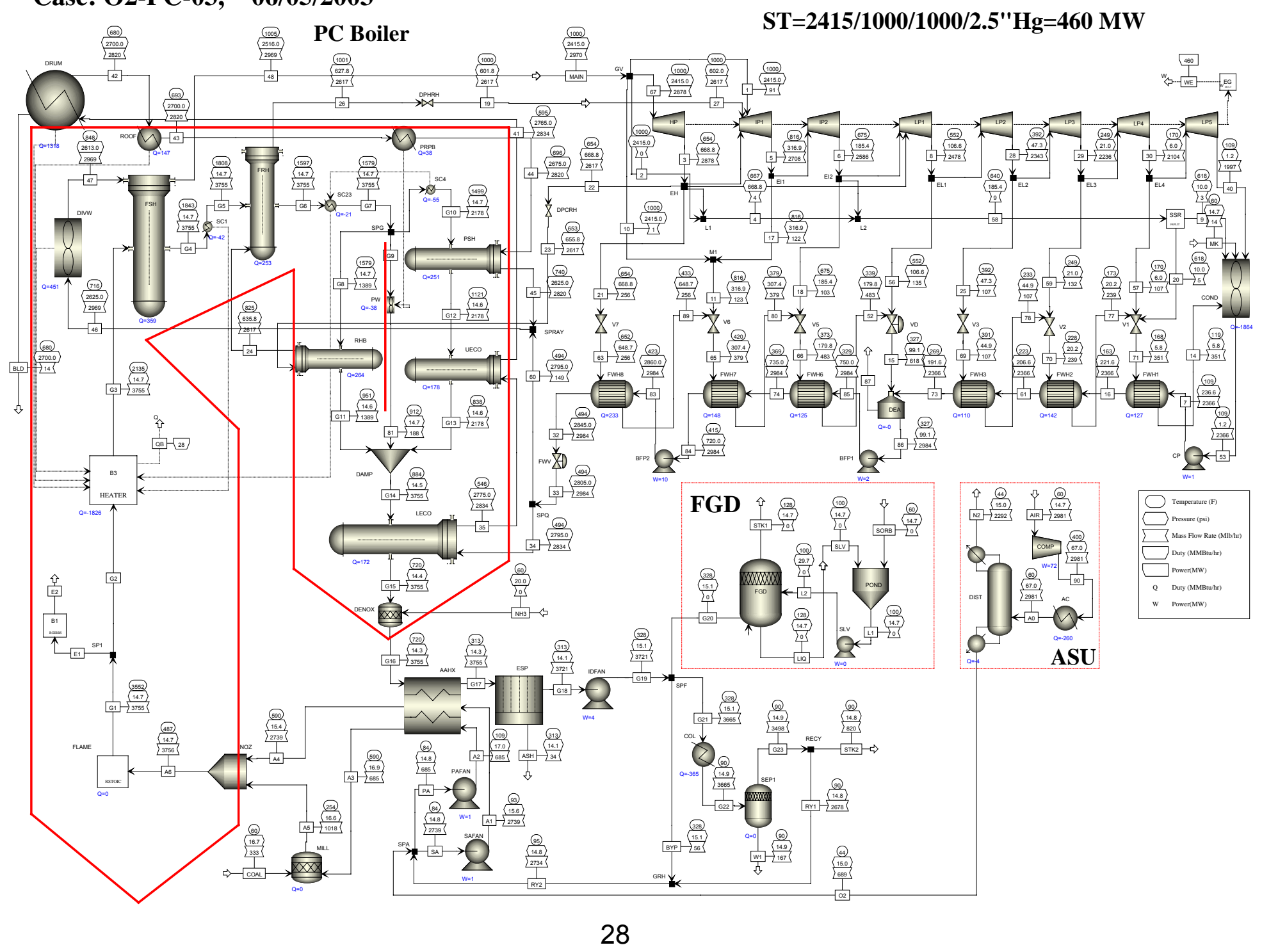




\section{Figure 9 - Case 4 Cycle Diagram}

Case: O2-PC-04, 06/05/2003

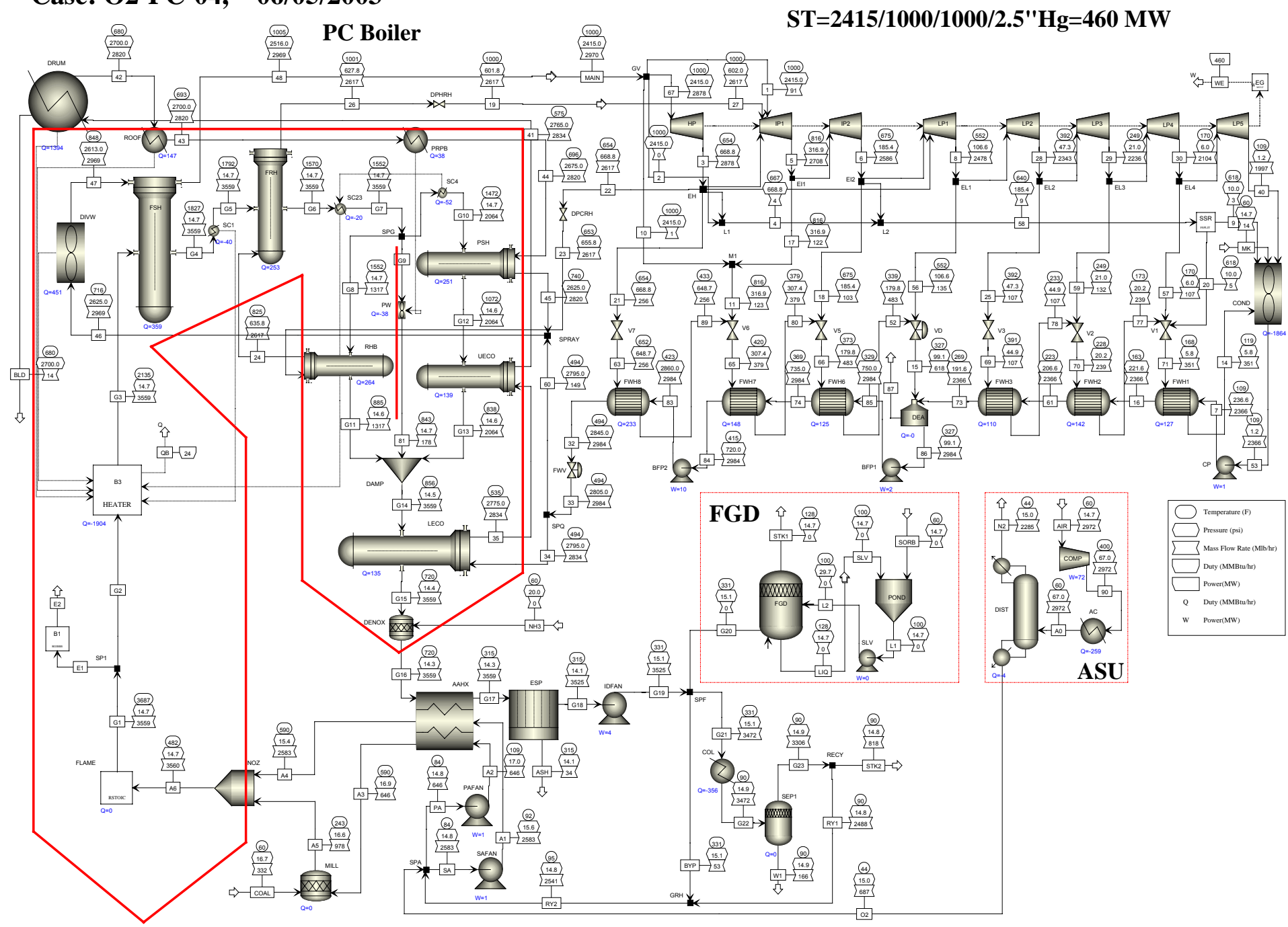




\section{Figure 10 - Case 5 Cycle Diagram}

Case: O2-PC-05, 06/05/2003

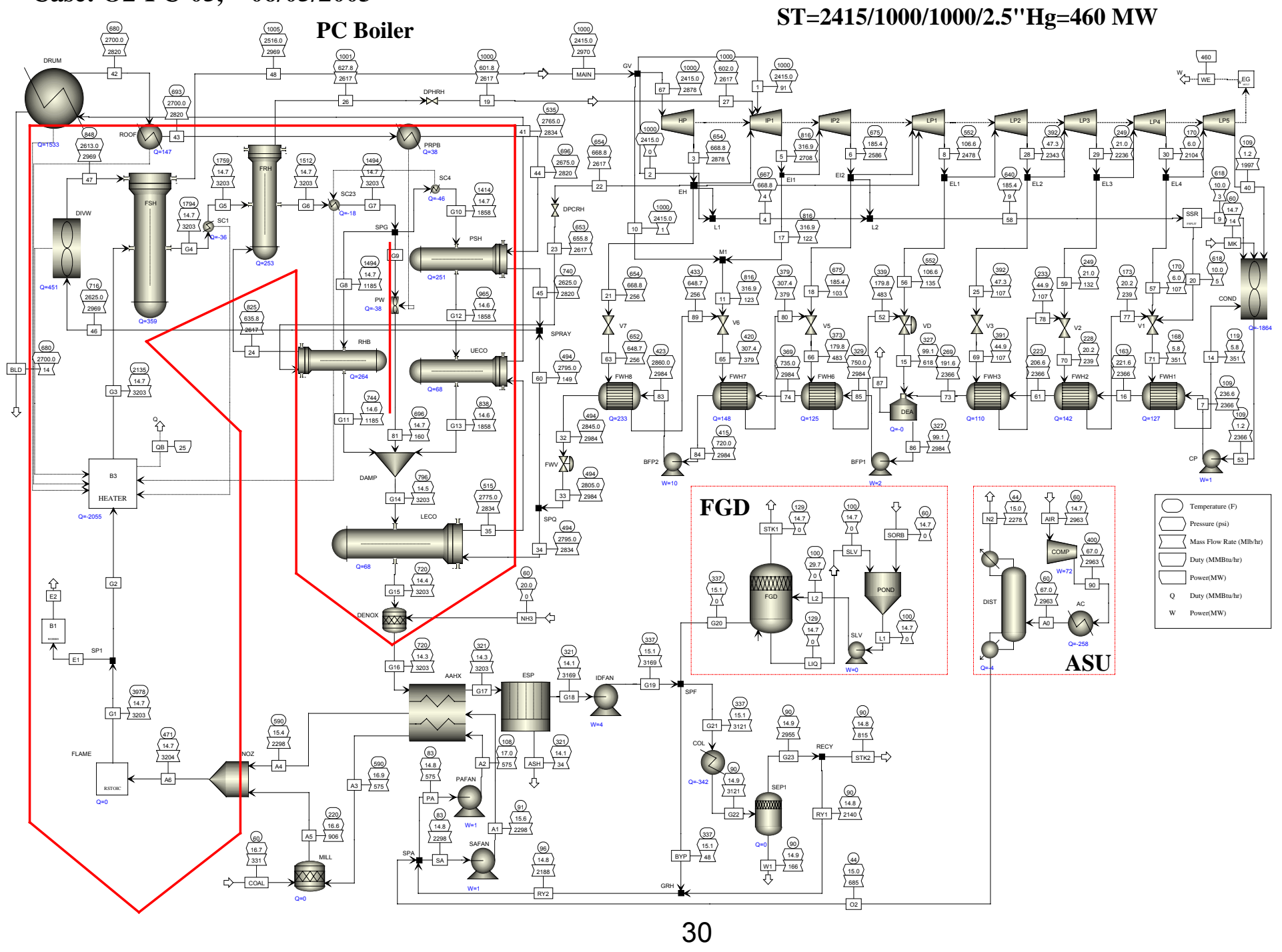




\section{Figure 11 - Case 6 Cycle Diagram}

Case: O2-PC-06, 06/05/2003

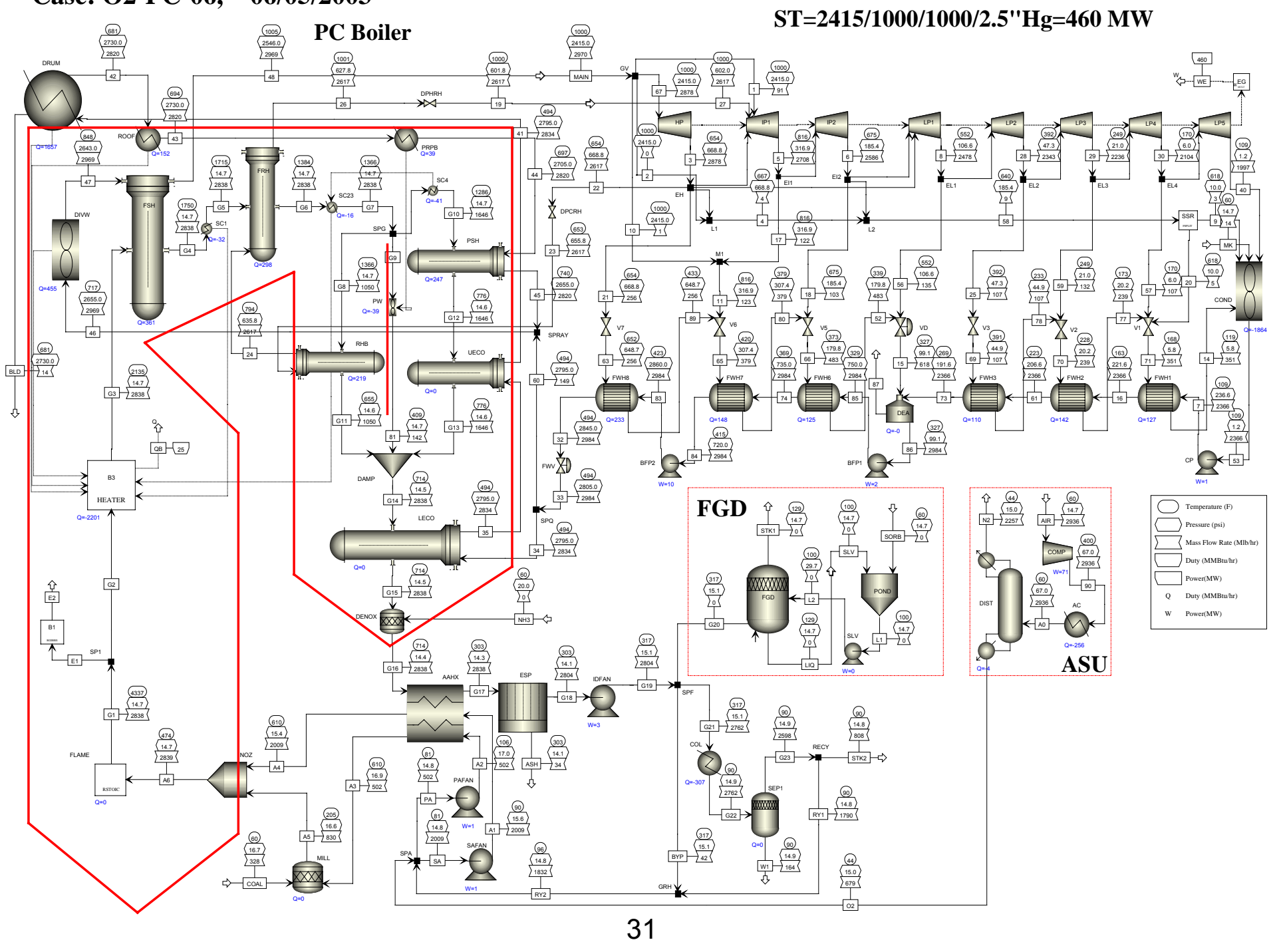




\section{Figure 12 - Case 7 Cycle Diagram}

Case: O2-PC-07， 06/05/2003

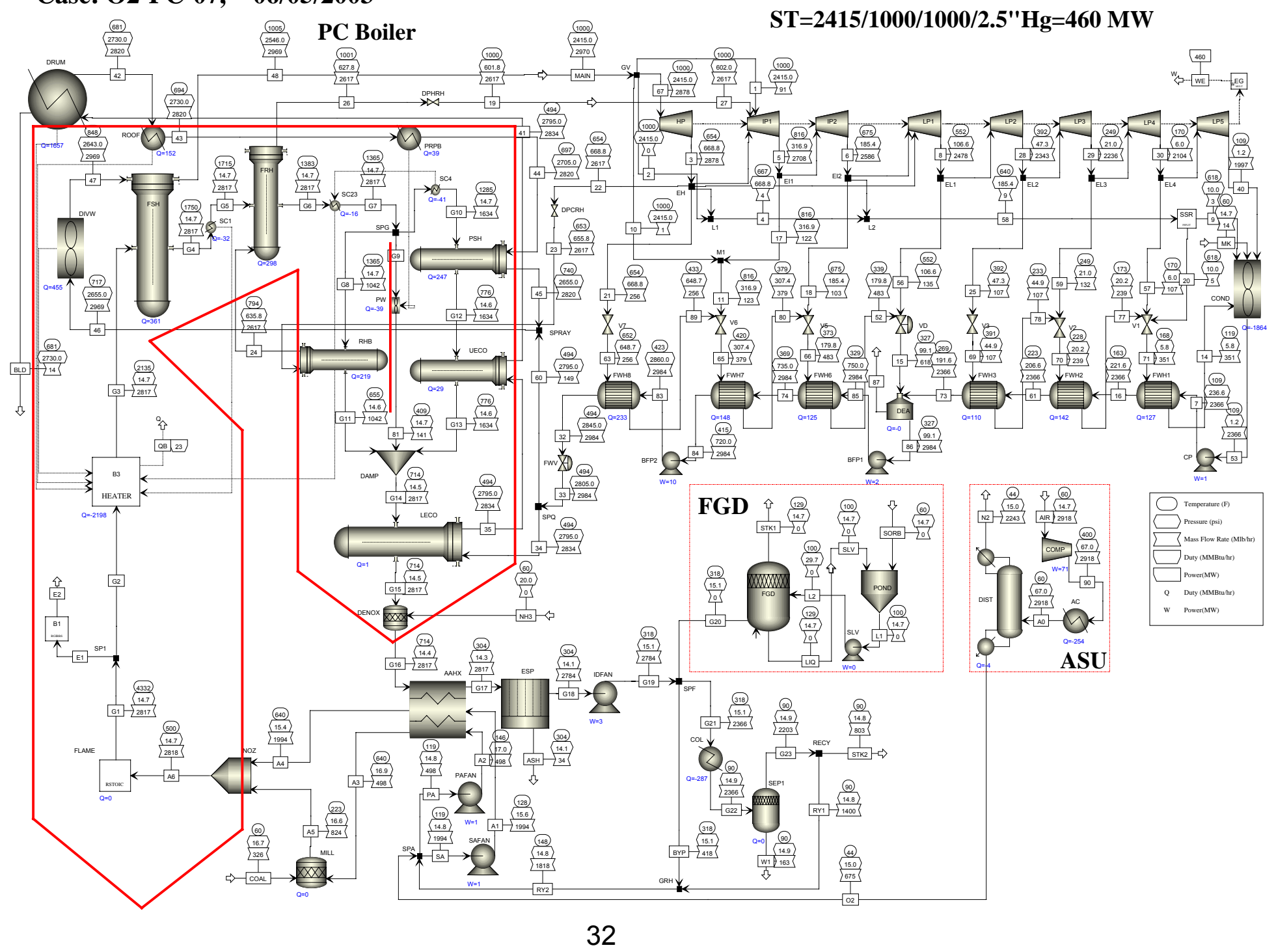


Figure 13 - Parametric Cases Summary (Without $\mathrm{CO}_{2}$ Compression)

\begin{tabular}{|l|c|c|c|c|c|c|c|}
\hline \multicolumn{1}{|c|}{ case } & $\mathbf{1}$ & $\mathbf{2}$ & $\mathbf{3}$ & $\mathbf{4}$ & $\mathbf{5}$ & $\mathbf{6}$ & $\mathbf{7}$ \\
\hline ASU & no & yes & yes & yes & yes & yes & yes \\
\hline coal to boiler, klb/h & 334 & 333 & 333 & 332 & 331 & 328 & 326 \\
\hline air to plant, klb/h & 3422 & 3422 & 2981 & 2972 & 2963 & 2936 & 2918 \\
\hline O2 purity, \% & 20.7 & 99.6 & 99.6 & 99.6 & 99.6 & 99.6 & 99.6 \\
\hline O2 level to boiler, \% & 20.4 & 39.7 & 26.9 & 28.1 & 30.9 & 34.1 & 33.7 \\
\hline O2 level exit boiler, \% & 3.0 & 15.3 & 3.0 & 3.0 & 3.0 & 3.0 & 3.0 \\
\hline Net EXA, \% & 18.0 & 18.0 & 3.1 & 3.1 & 3.0 & 3.2 & 3.2 \\
\hline Boiler EXA, \% & 18.0 & 69.1 & 13.6 & 12.5 & 11.2 & 10.4 & 10.4 \\
\hline flame T, F & 3687 & 3608 & 3574 & 3687 & 3978 & 4337 & 4332 \\
\hline gas to boiler exit, klb/h & 3721 & 3721 & 3721 & 3525 & 3169 & 2804 & 2784 \\
\hline gas to boiler exit, mmcft/h & 237 & 181 & 175 & 167 & 151 & 134 & 135 \\
\hline gas recycle to boiler, klb/h & 0 & 2632 & 2734 & 2541 & 2188 & 1832 & 1818 \\
\hline gas T before IDFan, F & 291 & 307 & 309 & 315 & 321 & 303 & 304 \\
\hline Recycled gas T, F & - & 95 & 95 & 95 & 95 & 96 & 148 \\
\hline gas exit system, klb/h & 3721 & 927 & 820 & 818 & 815 & 808 & 803 \\
\hline CO2, \%v & 14.0 & 76.4 & 89.6 & 89.6 & 89.6 & 89.6 & 89.6 \\
\hline ASU plant power, MW & 0 & 83.0 & 72.3 & 72.1 & 71.8 & 71.2 & 70.7 \\
\hline Aux power, MW & 42.1 & 116.7 & 105.8 & 105.3 & 104.4 & 102.7 & 102.5 \\
\hline Boiler eff, \% & 88.2 & 88.3 & 88.3 & 88.6 & 88.9 & 89.60 & 90.94 \\
\hline Net eff (w/o CO2), \% & 36.68 & 30.19 & 31.15 & 31.29 & 31.46 & 31.90 & 32.12 \\
\hline
\end{tabular}


Figure 14 - Net Efficiency (without $\mathrm{CO}_{2}$ compression) Versus Flame Temperature

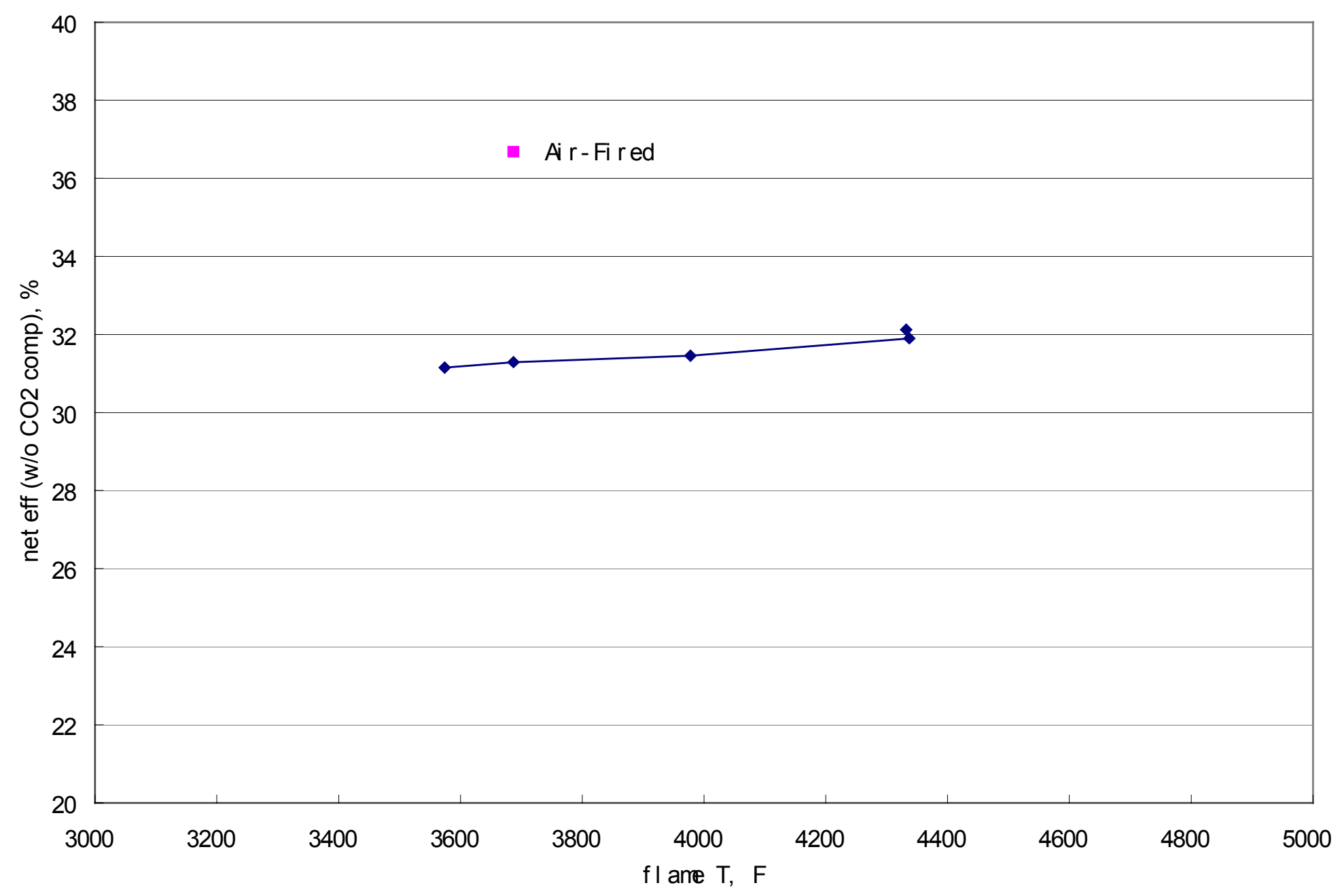


Figure 15 - ASU and Auxiliary Power Requirements Versus Flame Temperature

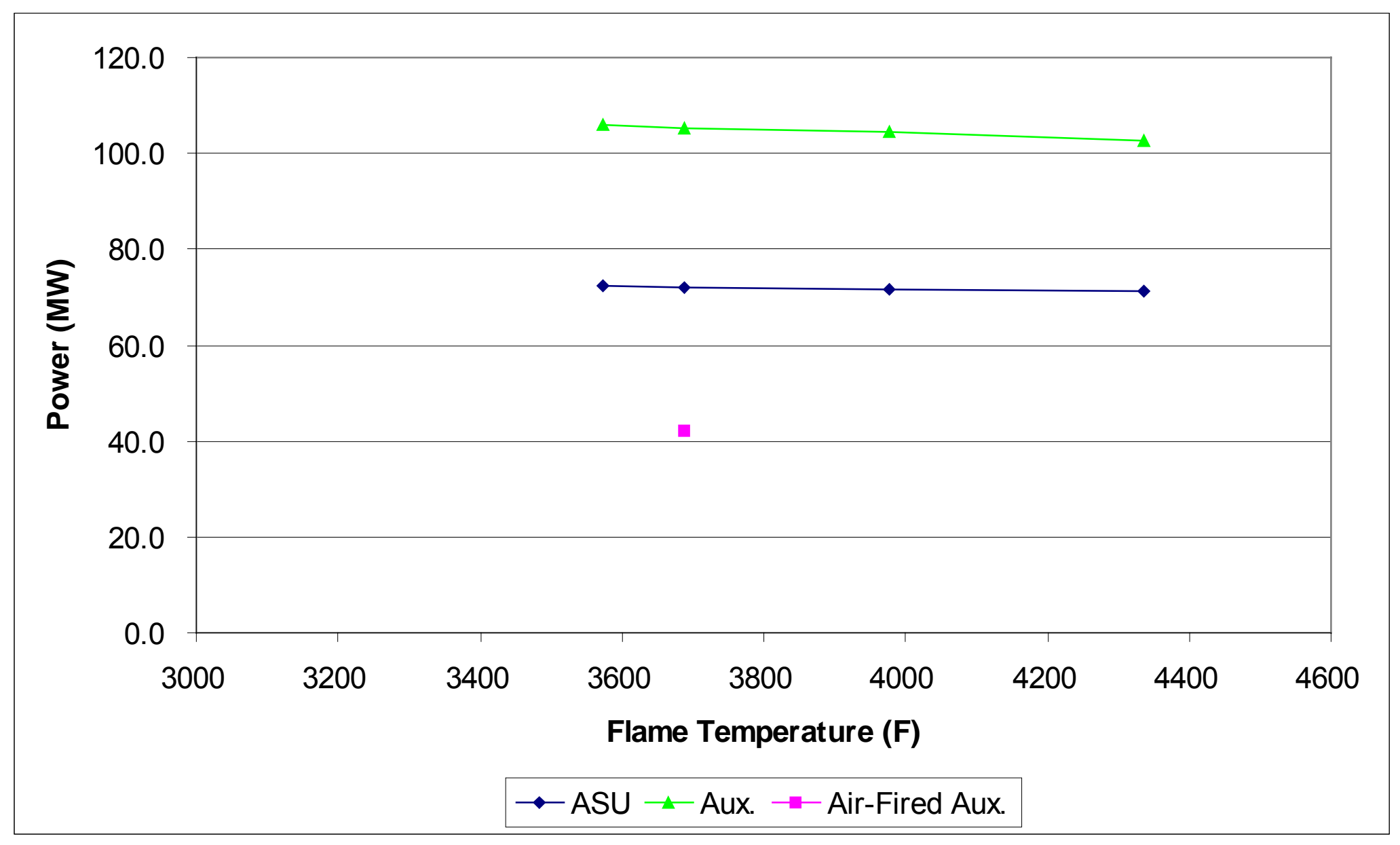


Figure 16 - Recycled Gas Mass Flow Rate Versus Flame Temperature

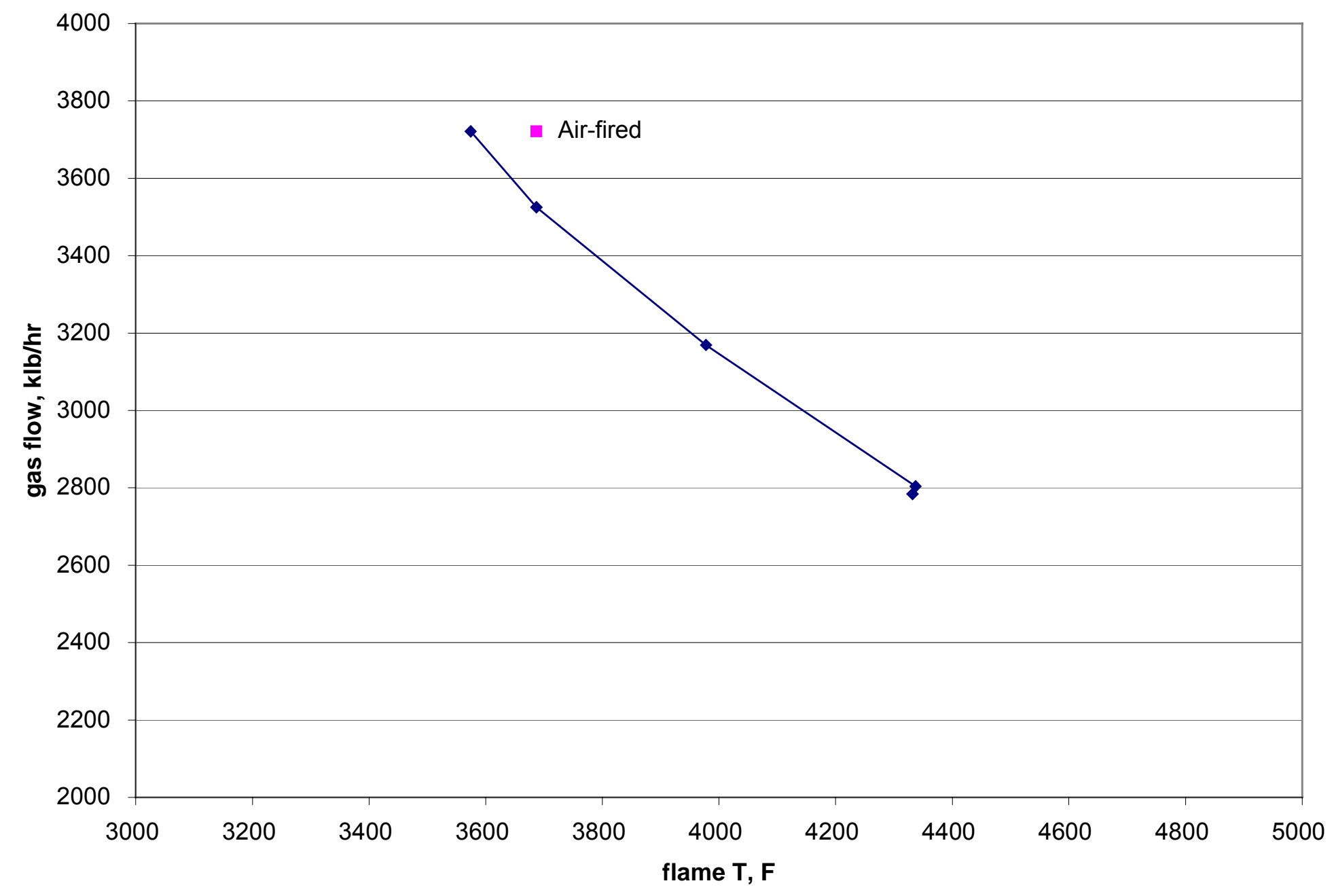


Figure 17 - Recycled Gas Volumetric Flow Rate Versus Flame Temperature

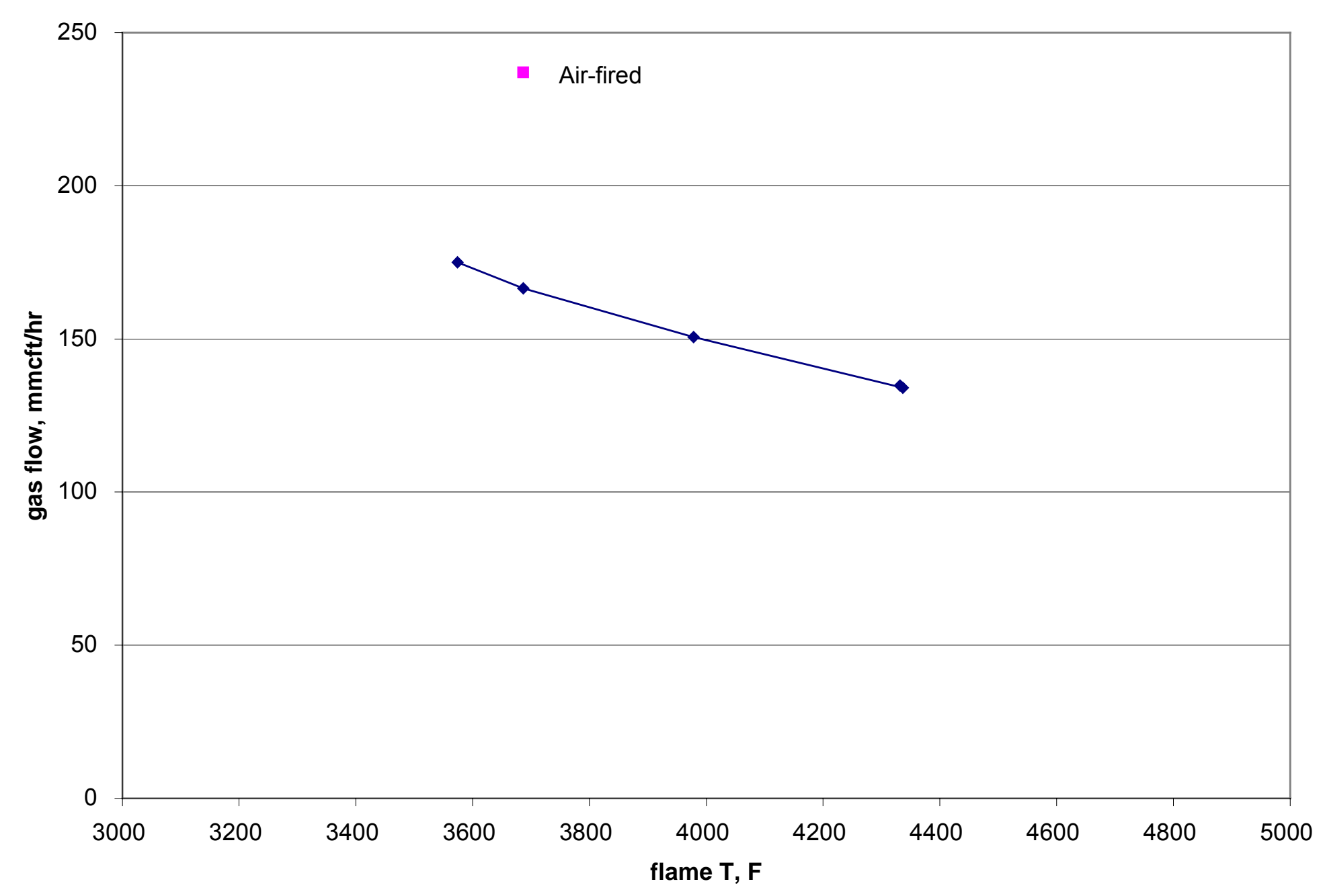


Figure 18 - Flue Gas Cooling Curve

\section{Cooling Curve}

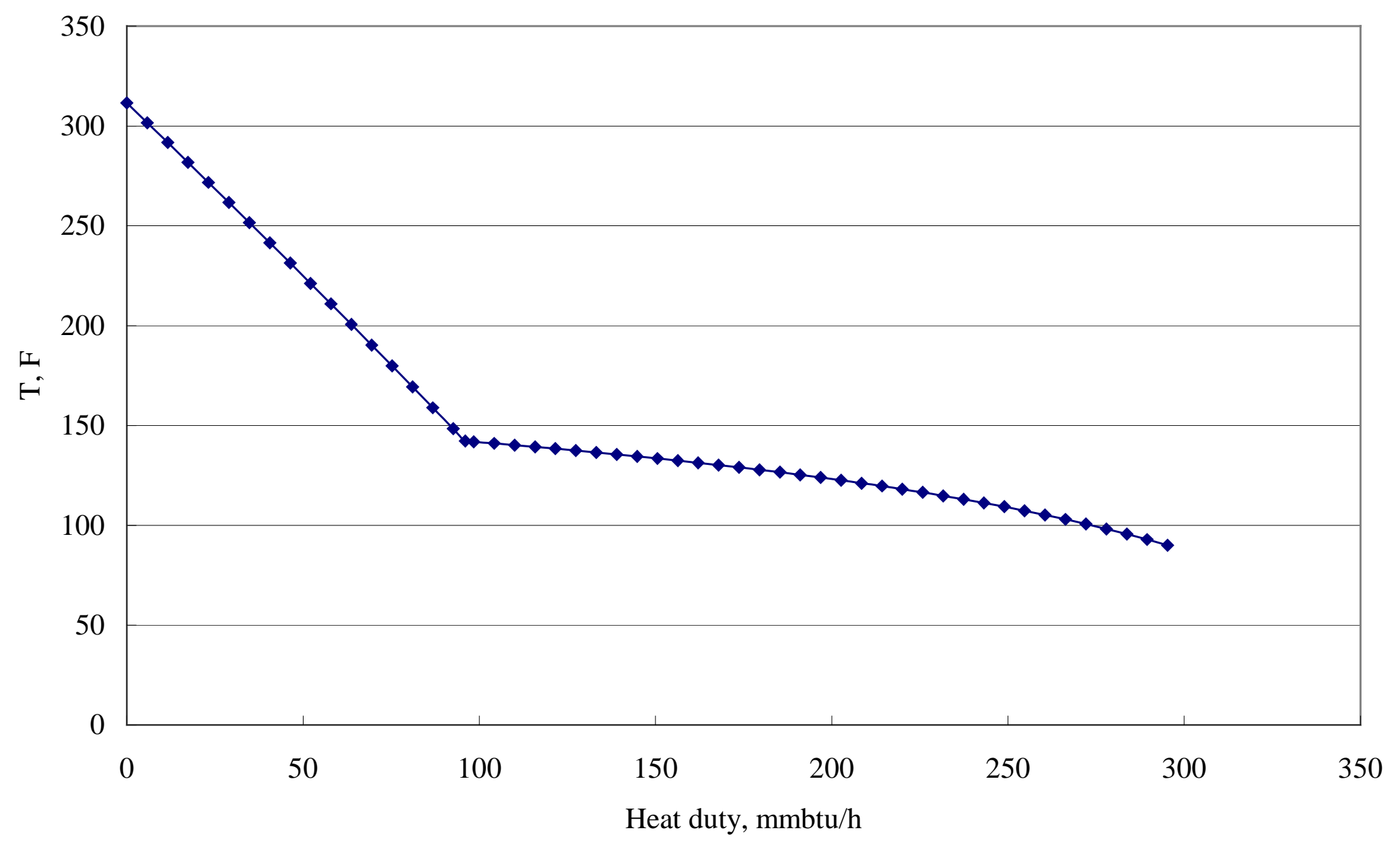




\section{Figure 19 - Case 8 Cycle Diagram}

\section{Case: O2-PC-11， 08/04/2003}

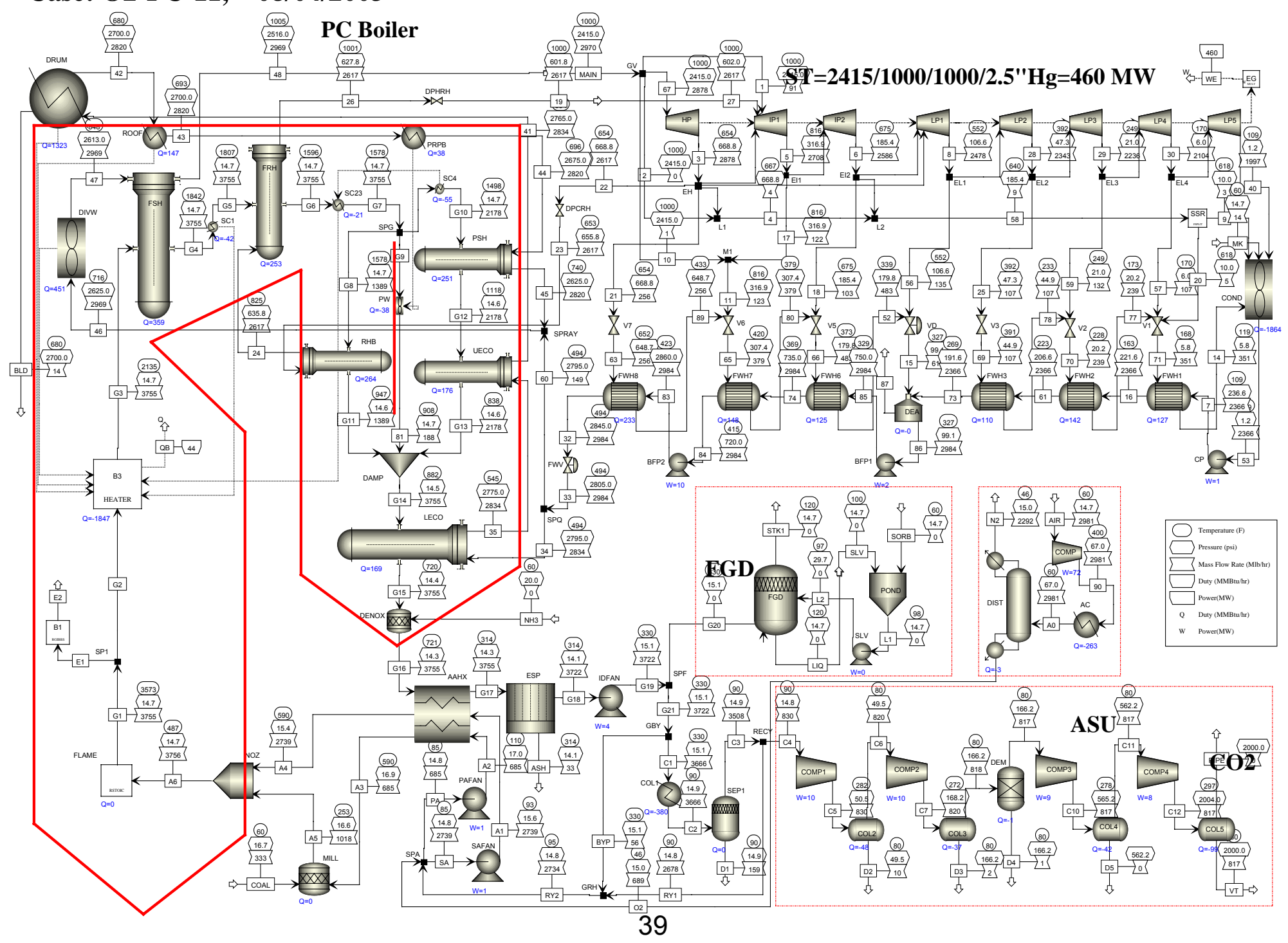




\section{Figure 20 - Case 9 Cycle Diagram}

\section{Case: O2-PC-12, 08/07/2003}

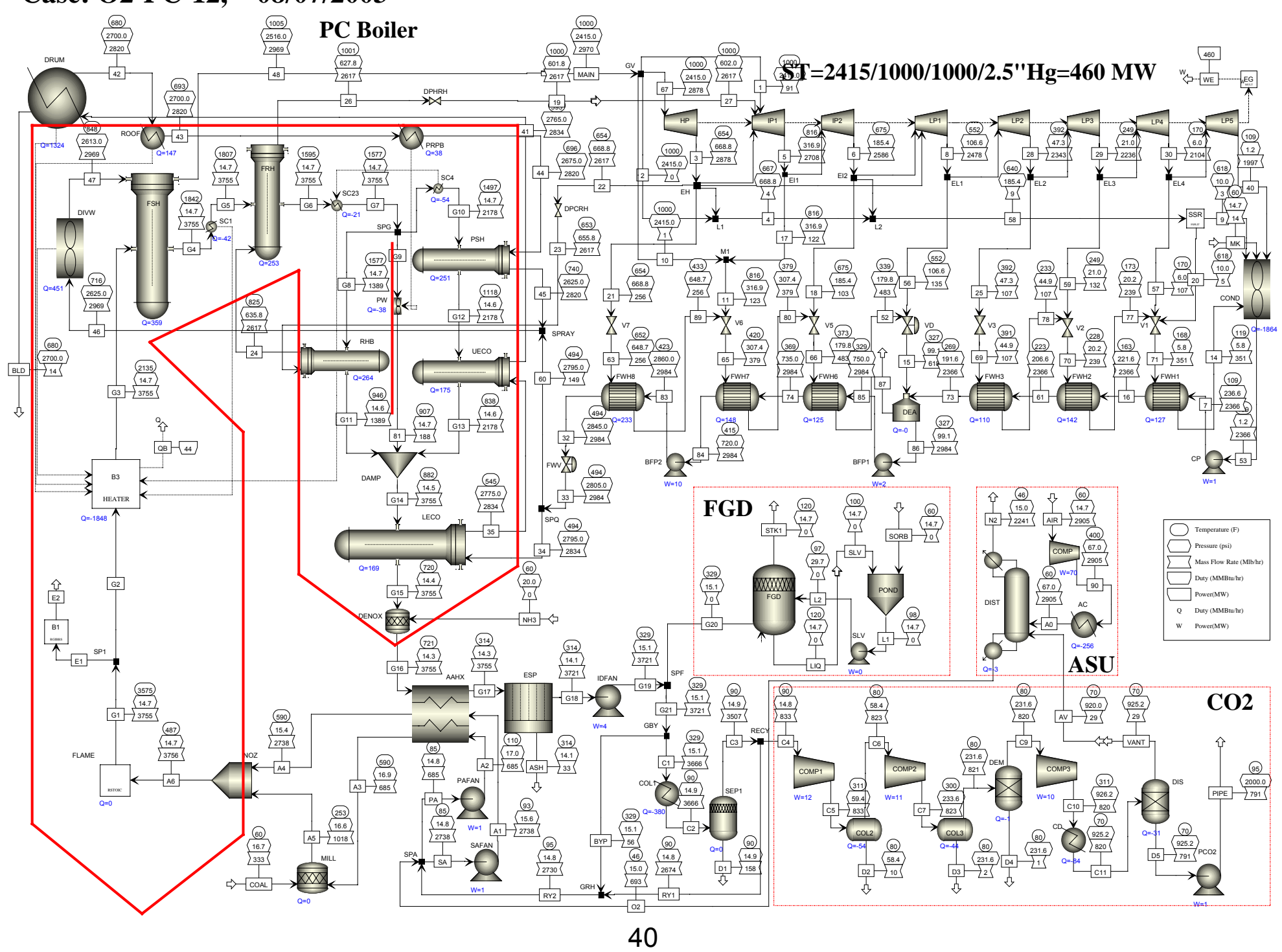




\section{Figure 21 - Case 10 Cycle Diagram}

Case: O2-PC-13， 09/08/2003

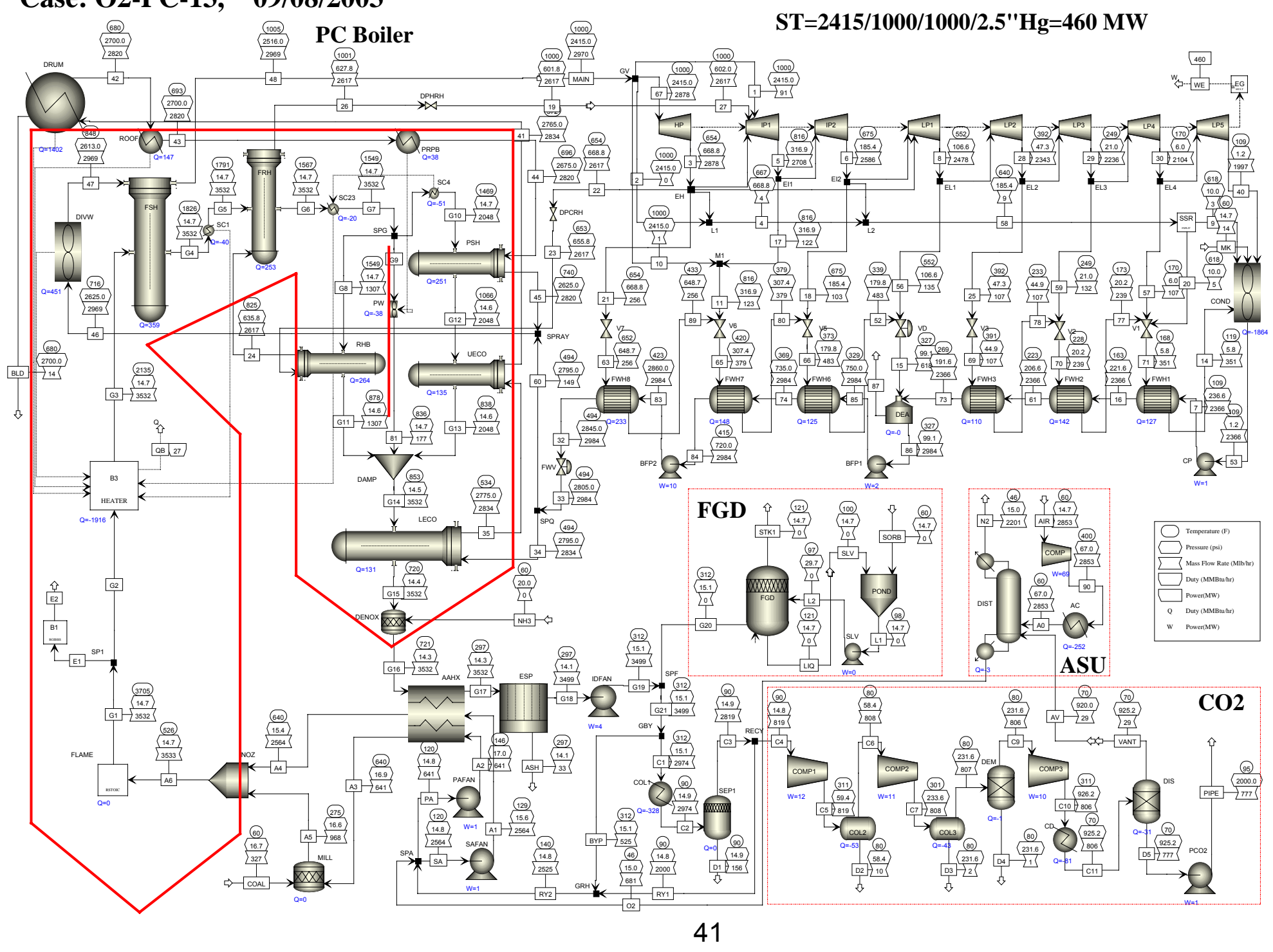




\section{Figure 22 - Case 11 Cycle Diagram}

Case: O2-PC-14, 10/22/2003

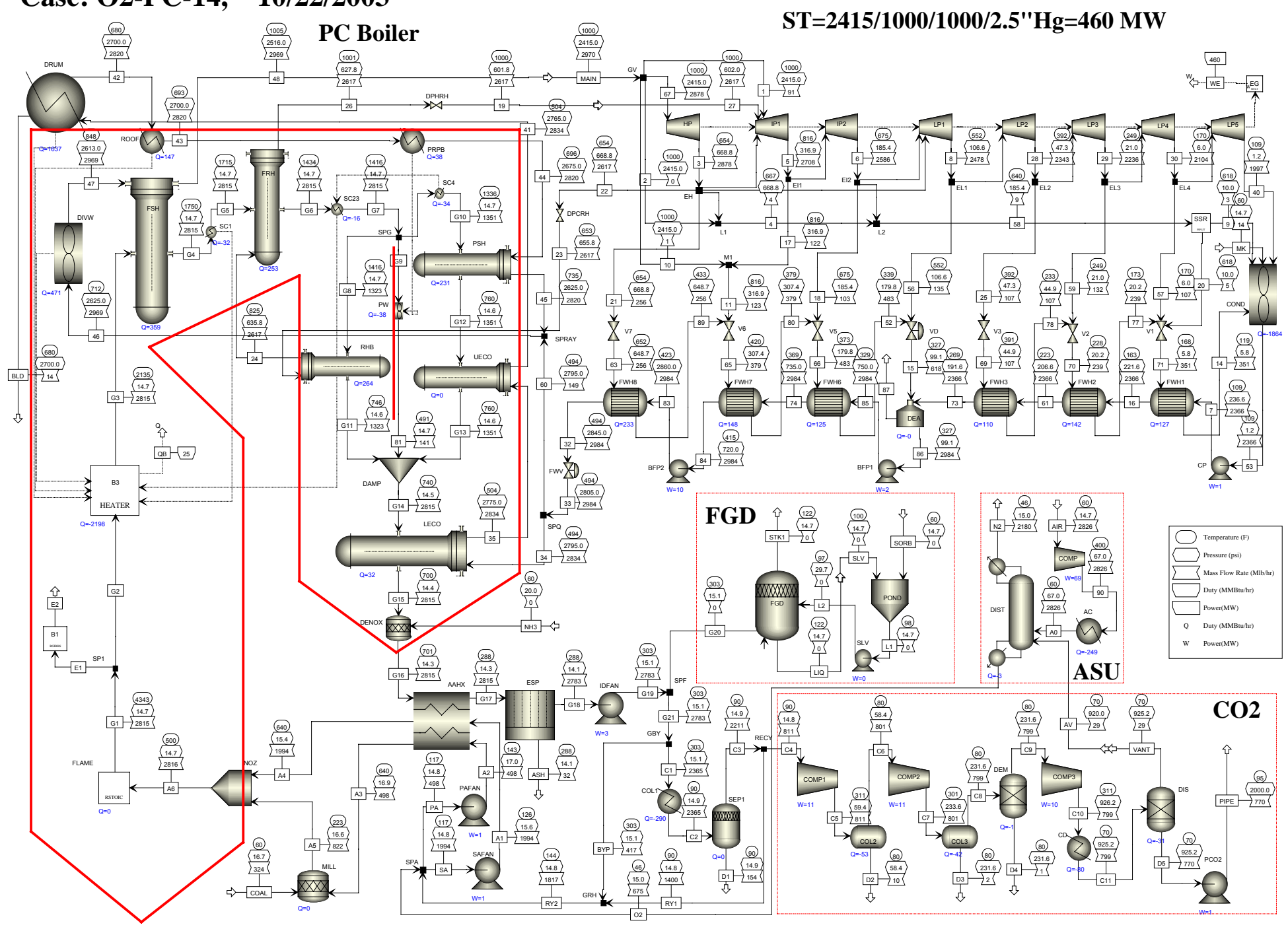


Figure 23 - Parametric Cases Summary (With $\mathrm{CO}_{2}$ Compression)

\begin{tabular}{|c|c|c|c|c|c|c|c|}
\hline case & 1 & 3 & 8 & 9 & 10 & 11 & 12 \\
\hline ASU & no & yes & yes & yes & yes & yes & yes \\
\hline CO2 Sequestration & no & no & yes & yes & yes & yes & yes \\
\hline Vent gas recover & no & no & no & yes & yes & yes & yes \\
\hline Wet-end economizer & no & no & no & no & no & no & yes \\
\hline coal to boiler, klb/h & 334 & 333 & 333 & 333 & 327 & 324 & 324 \\
\hline air to plant, klb/h & 3422 & 2981 & 2981 & 2905 & 2853 & 2826 & 2826 \\
\hline O2 purity, $\%$ & 20.7 & 99.6 & 99.6 & 99.5 & 99.5 & 99.5 & 99.5 \\
\hline O2 level to boiler, \% & 20.4 & 26.9 & 26.7 & 27.1 & 28.0 & 33.9 & 33.9 \\
\hline O2 level exit boiler, \% & 3.0 & 3.0 & 3.0 & 3.0 & 3.0 & 3.0 & 3.0 \\
\hline Excess Air, \% & 18.0 & 3.1 & 3.1 & 0.3 & 0.3 & 0.3 & 0.3 \\
\hline flame $\mathrm{T}, \mathrm{F}$ & 3687 & 3574 & 3573 & 3575 & 3705 & 4343 & 4343 \\
\hline gas to boiler exit, klb/h & 3721 & 3721 & 3722 & 3721 & 3499 & 2783 & 2783 \\
\hline gas to boiler exit, mmcft/h & 237 & 175 & 175 & 174 & 166 & 134 & 134 \\
\hline gas recycle to boiler, $\mathrm{klb} / \mathrm{h}$ & 0 & 2734 & 2734 & 2730 & 2525 & 1817 & 1817 \\
\hline gas exit system, klb/h & 3721 & 820 & 820 & 833 & 819 & 811 & 811 \\
\hline ASU plant power, MW & 0 & 72.3 & 72.3 & 70.5 & 69.2 & 68.6 & 68.6 \\
\hline CO2 compression power, MW & 0 & 0 & 37.2 & 34.6 & 34.0 & 33.7 & 33.7 \\
\hline Gross power, MW & 460 & 460 & 460.0 & 460.0 & 460.0 & 460.0 & 464 \\
\hline Aux power, MW & 42.1 & 105.8 & 143.1 & 138.6 & 136.4 & 133.9 & 134.6 \\
\hline Net Power, MW & 417.9 & 354.2 & 317.3 & 321.8 & 324.0 & 326.5 & 329.6 \\
\hline Boiler efficiency, \% & 88.2 & 88.3 & 88.3 & 88.3 & 89.9 & 90.8 & 93.2 \\
\hline Net efficiency, \% & 36.68 & 31.15 & 27.87 & 28.27 & 28.98 & 29.48 & 29.75 \\
\hline
\end{tabular}


Figure 24 - Vapor Pressure of $\mathrm{CO}_{2}$

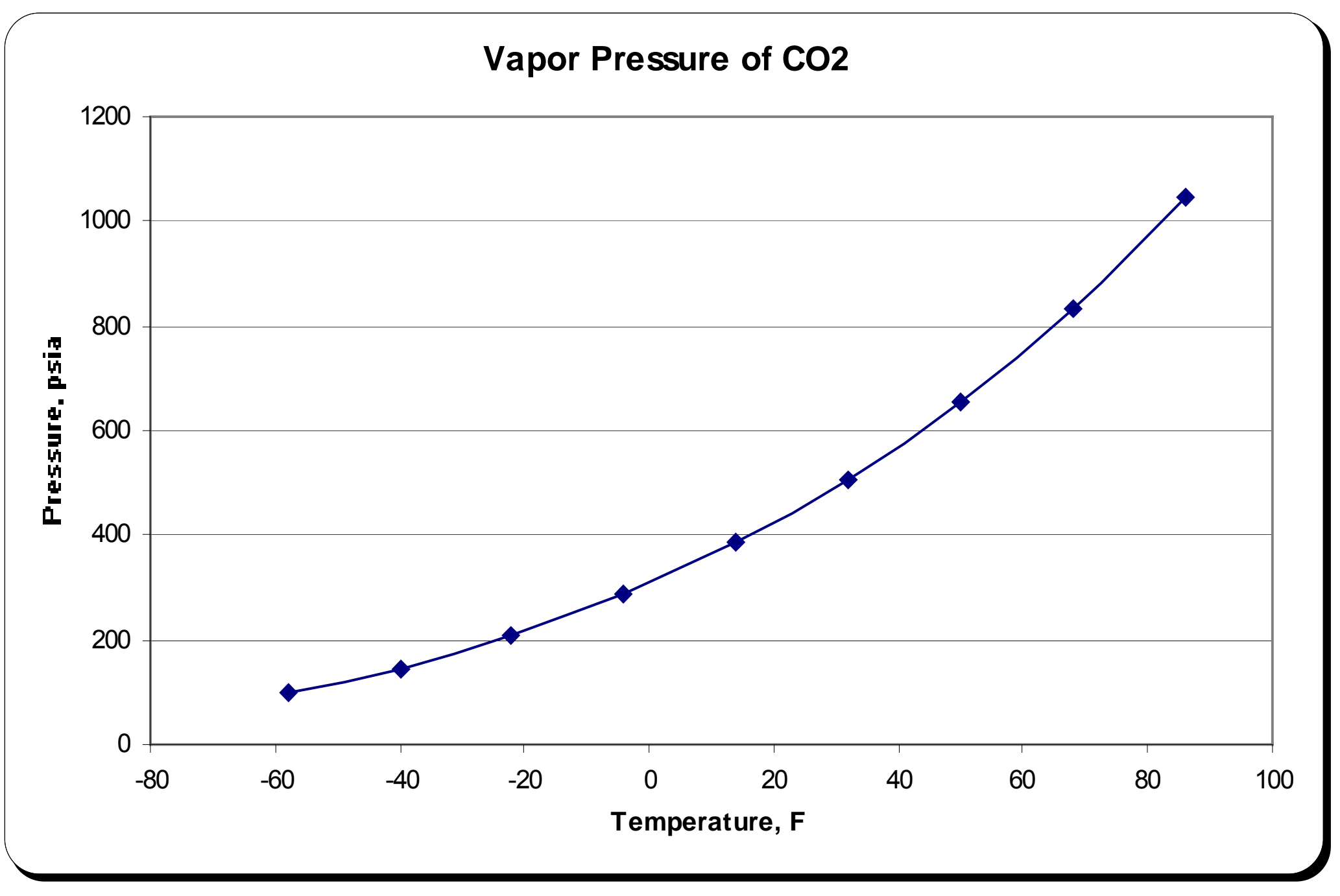


Figure 25 - Radiation Heat Flux and Water Wall Temperature

\begin{tabular}{|c|c|c|c|c|c|c|c|c|c|c|c|c|}
\hline & & 1 & 2 & 3 & 4 & 5 & 6 & 7 & 8 & 9 & 10 & 11,12 \\
\hline Gas Flow Rate & $\mathrm{MM} \mathrm{ft3/hr}$ & 237.0 & 181.0 & 175.0 & 166.5 & 150.6 & 134.0 & 134.8 & 175.0 & 174.4 & 166.0 & 134.0 \\
\hline Furnace Heat Duty & MM Btu/hr & 1894 & 1848 & 1826 & 1904 & 2055 & 2201 & 2198 & 1847 & 1848 & 1916 & 2198 \\
\hline Furnace $\mathrm{H} 2 \mathrm{O}$ & $\%$ & 5.0 & 11.1 & 11.6 & 11.9 & 12.8 & 13.8 & 15.2 & 11.1 & 11.0 & 12.6 & 14.7 \\
\hline Furnace $\mathrm{CO} 2$ & $\%$ & 7.0 & 59.2 & 68.9 & 68.6 & 67.8 & 66.9 & 65.5 & 69.8 & 69.4 & 67.8 & 65.9 \\
\hline Depth & $\mathrm{ft}$ & 35.9 & 31.3 & 30.8 & 30.1 & 28.6 & 27.0 & 27.0 & 30.8 & 30.8 & 30.0 & 27.0 \\
\hline Width & $\mathrm{ft}$ & 51.0 & 44.6 & 43.8 & 42.7 & 40.6 & 38.3 & 38.5 & 43.8 & 43.7 & 42.7 & 38.3 \\
\hline Height & $\mathrm{ft}$ & 206.9 & 155.7 & 155.0 & 155.8 & 153.4 & 142.2 & 139.9 & 158.1 & 158.8 & 154.5 & 140.2 \\
\hline Mean Beam Length & $\mathrm{ft}$ & 30.9 & 26.2 & 25.8 & 25.2 & 24.0 & 22.5 & 22.5 & 25.9 & 25.8 & 25.1 & 22.5 \\
\hline Tube wall Properties & & & & & & & & & & & & \\
\hline Outside Diameter & in & 2.75 & 2.75 & 2.75 & 2.75 & 2.75 & 2.75 & 2.75 & 2.75 & 2.75 & 2.75 & 2.75 \\
\hline Wall Thickness & in & 0.285 & 0.285 & 0.285 & 0.285 & 0.285 & 0.24 & 0.24 & 0.285 & 0.285 & 0.285 & 0.24 \\
\hline Inside Diameter & in & 2.18 & 2.18 & 2.18 & 2.18 & 2.18 & 2.27 & 2.27 & 2.18 & 2.18 & 2.18 & 2.27 \\
\hline inside H.T.C. & Btu/hr-ft2-F & 2500 & 2500 & 2500 & 2500 & 2500 & 2500 & 2500 & 2500 & 2500 & 2500 & 2500 \\
\hline Material & & SA-210C & SA-213-T2 & SA-213-T2 & SA-213-T2 & SA-213-T22 & SA-213-T91 & SA-213-T91 & SA-213-T2 & SA-213-T2 & SA-213-T2 & SA-213-T91 \\
\hline Wall Therm. Cond. & Btu/hr-ft-F & 22.0 & 21.8 & 22.2 & 22.2 & 20.0 & 16.1 & 16.1 & 22.2 & 22.2 & 22.2 & 16.1 \\
\hline Overall U & Btu/hr-ft2-F & 583.3 & 579.6 & 587.0 & 587.0 & 544.9 & 540.6 & 540.6 & 587.0 & 587.0 & 587.0 & 540.6 \\
\hline Stress Allowable & psi & 12,663 & 14,514 & 14,506 & 14,388 & 12,794 & 17,722 & 17,661 & 14,512 & 14,515 & 14,353 & 17,640 \\
\hline Min. Wall & in & 0.29 & 0.26 & 0.26 & 0.26 & 0.29 & 0.22 & 0.22 & 0.26 & 0.26 & 0.26 & 0.22 \\
\hline Max. Furnace Temp. & $\mathrm{F}$ & 3587 & 3508 & 3474 & 3587 & 3878 & 4237 & 4232 & 3473 & 3475 & 3605 & 4243 \\
\hline Max. Heat Flux & Btu/hr-ft2 & 63,090 & 97,505 & 99,320 & 105,300 & 127,712 & 147,366 & 148,470 & 98,880 & 98,725 & 106,975 & 148,850 \\
\hline Max. Wall Temp. & $\mathrm{F}$ & 788 & 848 & 849 & 859 & 914 & 953 & 955 & 848 & 848 & 862 & 955 \\
\hline Ave. Furnace Temp. & $\mathrm{F}$ & 3079 & 3020 & 2995 & 3079 & 3299 & 3579 & 3575 & 2994 & 2995 & 3092 & 3583 \\
\hline Ave. Wall Flux & Btu/hr-ft2 & 47,830 & 69,904 & 70,688 & 75,380 & 87,224 & 106,620 & 107,710 & 70,244 & 70,126 & 76,579 & 107,829 \\
\hline flux/flux(case1) & & 1.00 & 0.68 & 0.68 & 0.63 & 0.55 & 0.45 & 0.44 & 0.68 & 0.68 & 0.62 & 0.44 \\
\hline
\end{tabular}




\section{Figure 26 - Case 12 Cycle Diagram}

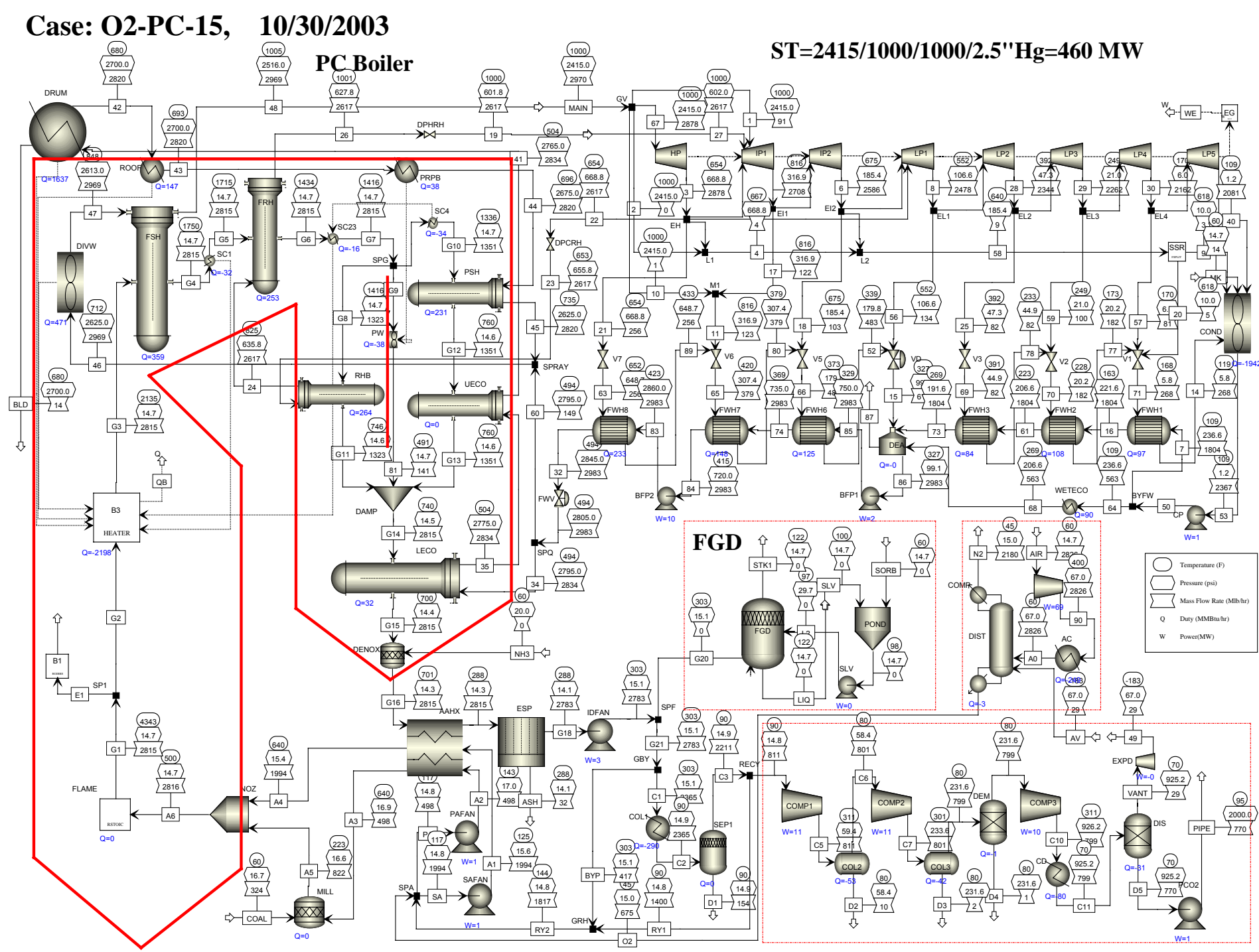


Figure 27 - Wet End Economizer Temperature Vs. Heat Duty

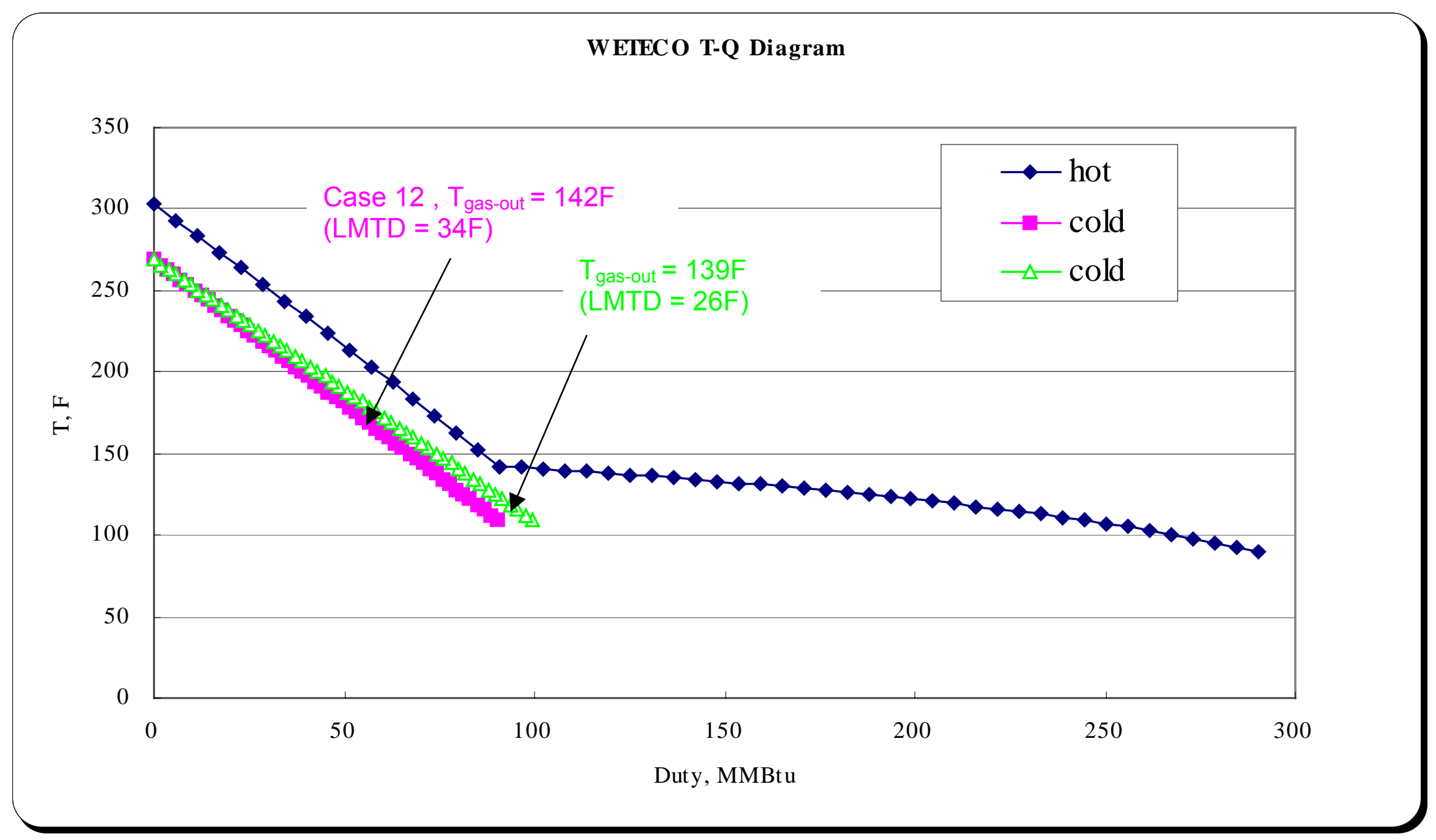


Figure 28 - Efficiency of Saved Extraction Steam Versus Stage

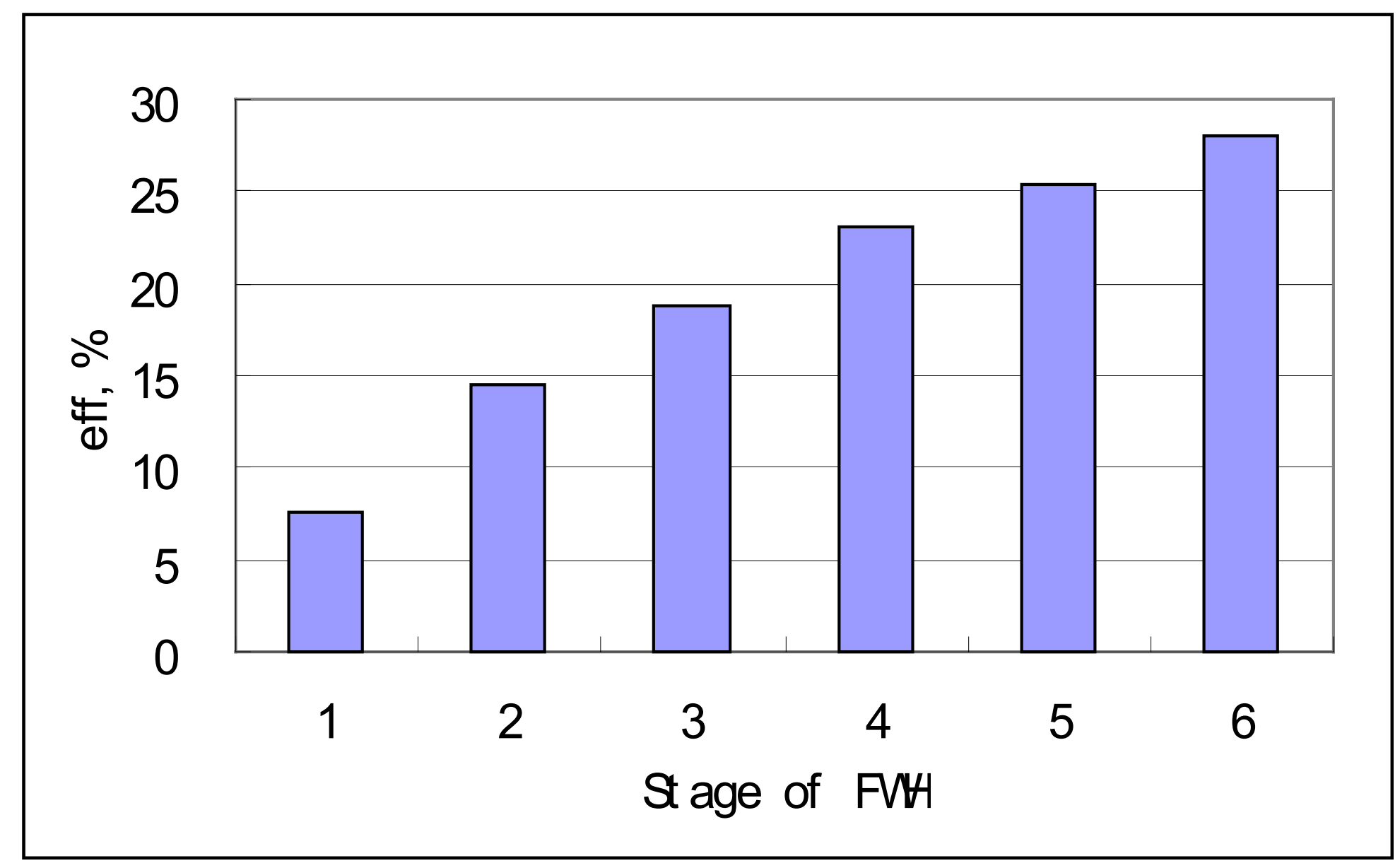


Figure 29 - Comparison of Power Consumption of $\mathrm{CO}_{2}$ Removal of Different Technologies

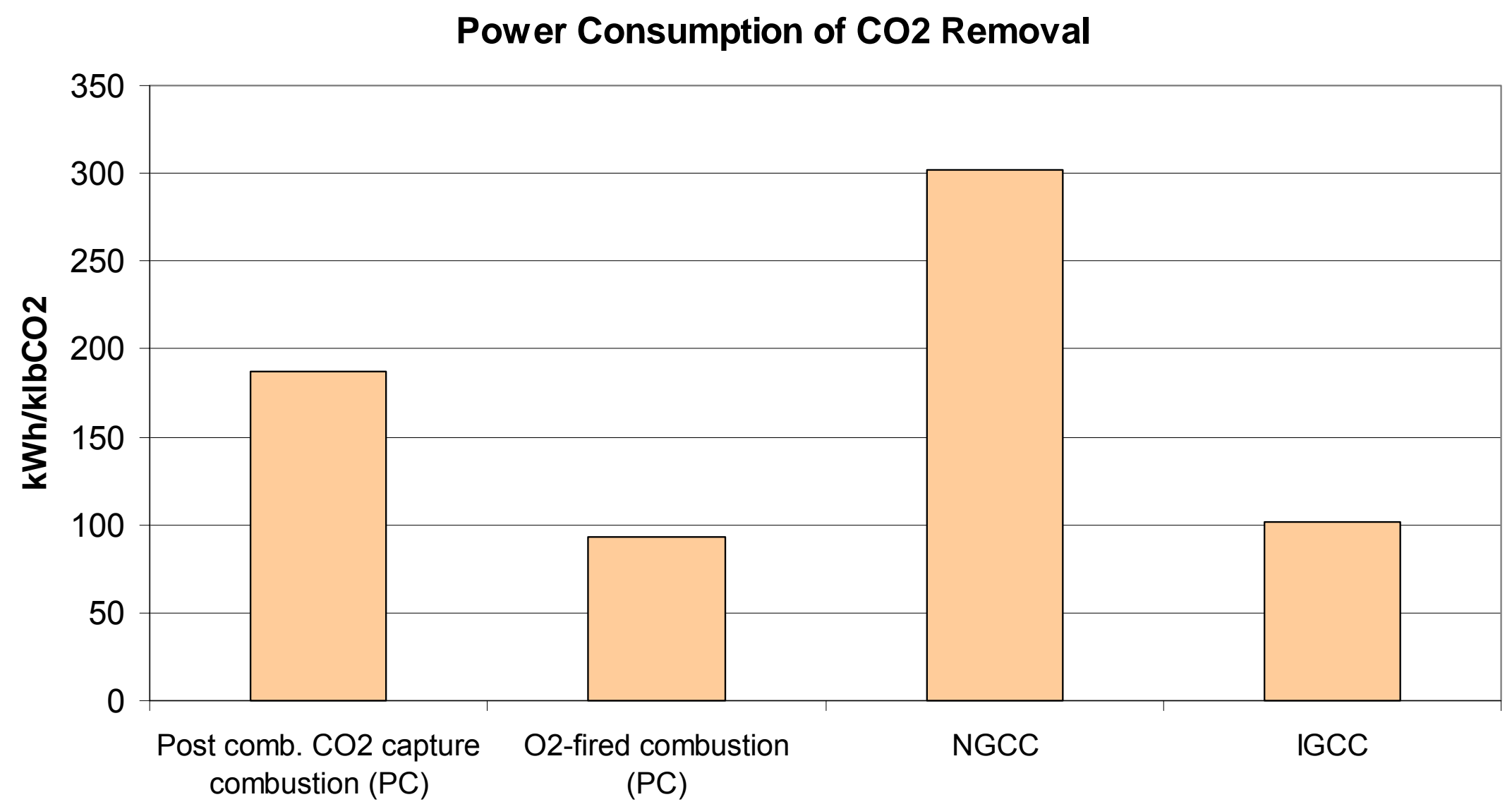


Figure 30 - Comparison of Overall Cycle Efficiency Point of $\mathrm{CO}_{2}$ Removal of Different Technologies

\section{Efficency Point Reduction of CO2 Removal}

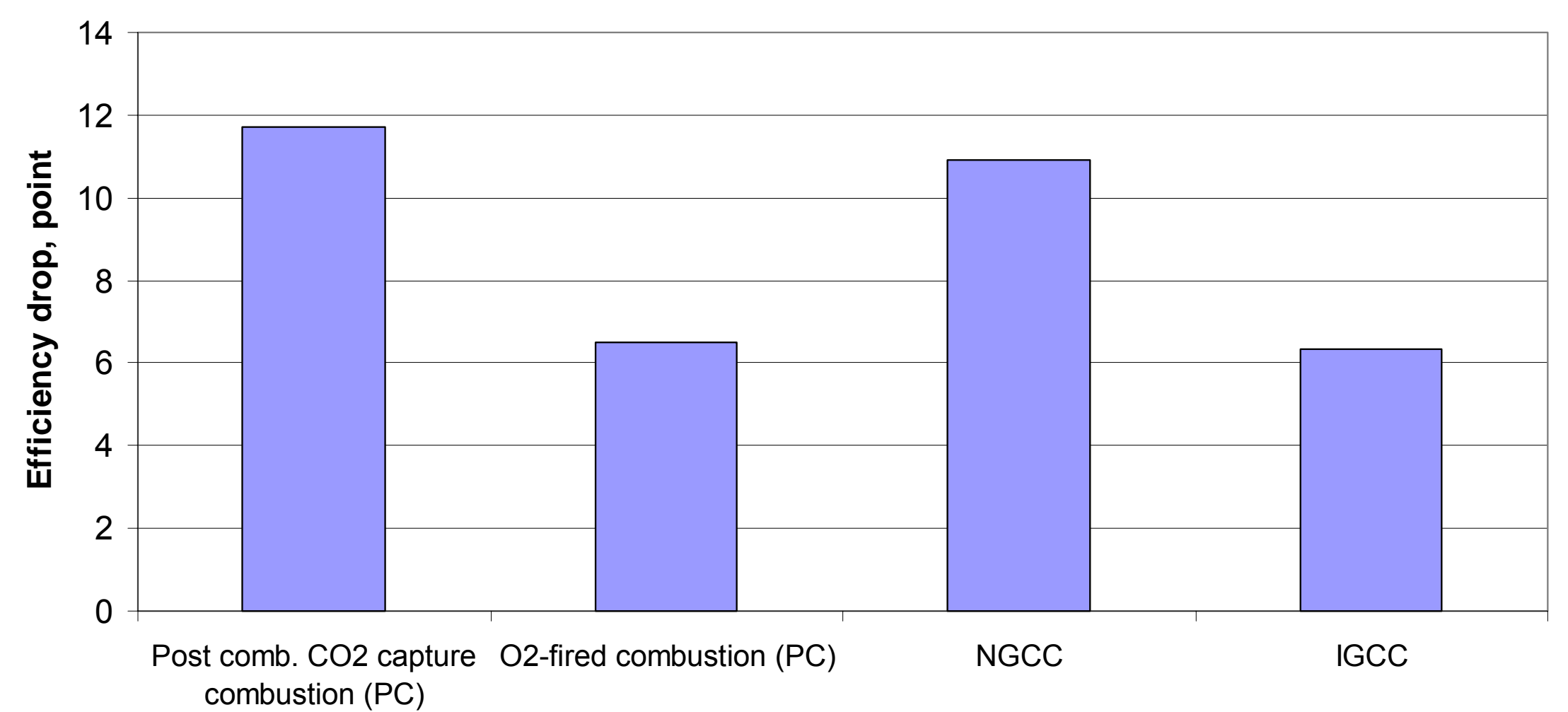




\subsection{Conclusion}

To assure continued U.S. power generation from its abundant domestic coal resources, new coal combustion technologies must be developed to meet future emissions standards, especially $\mathrm{CO}_{2}$ sequestration. Current conventional coalfired boiler plants burn coal using $15-20 \%$ excess air producing a flue gas, which is only approximately $15 \% \mathrm{CO}_{2}$. Consequently, $\mathrm{CO}_{2}$ sequestration requires noncondensable gases stripping, which is both expensive and highly powerconsumptive. Several different technologies for concentrating the $\mathrm{CO}_{2}$ by removing the non-condensable gases have been proposed including aminebased absorption and membrane gas absorption. However, these techniques require substantial energy, typically from low-pressure steam.

A new boiler is presented where the combustion air is separated into $\mathrm{O}_{2}$ and $\mathrm{N}_{2}$ and the boiler uses the $\mathrm{O}_{2}$, mixed with recycled flue gas, to combust the coal. The products of combustion are thus only $\mathrm{CO}_{2}$ and water vapor. The water vapor is easily condensed, yielding a pure $\mathrm{CO}_{2}$ stream ready for sequestration. The $\mathrm{CO}_{2}$ effluent is in a liquid form and is piped from the plant to the sequestration site. The combustion facility is thus truly a zero emission stackless plant.

The efficiency and cost-effectiveness of carbon sequestration in oxygen-firing boilers can rival competing gasification plants by specifically tailoring boiler design by appropriate surface location, combustion system design, material selection, furnace layout, and water/steam circuitry. Boiler efficiencies of near $100 \%$ can be achieved by recovery of virtually all of the flue gas exhaust sensible and latent heat. Boiler size can be drastically reduced due to higher radiative properties of $\mathrm{O}_{2}$-combustion versus air-combustion. Furthermore, a wider range of fuels can be burned due to the high oxygen content of the combustion gas and potential for high coal preheat.

A conceptual design of a $\mathrm{CO}_{2}$ sequestration-ready oxygen-based 460 Mwe PC boiler plant was developed. The selected $\mathrm{O}_{2}$-fired design case has a system efficiency of $30.1 \%$ compared to the air-fired system efficiency of $36.7 \%$. The design $\mathrm{O}_{2}$-fired case requires T91 waterwall material and has a waterwall surface area of only $44 \%$ of the air-fired reference case. Compared to other $\mathrm{CO}_{2}$ sequestration technologies, the $\mathrm{O}_{2}$-fired $\mathrm{PC}$ is substantially better than both natural gas combined cycles and post $\mathrm{CO}_{2}$ removal PCs and is slightly better than integrated gasification combined cycles. Furthermore, of the $\mathrm{CO}_{2}$ sequestration-ready technologies, the $\mathrm{O}_{2}$-fired $\mathrm{PC}$ is the simplest, requires the least modification of existing proven designs, and requires no special chemicals for $\mathrm{CO}_{2}$ separation.

Thus $\mathrm{CO}_{2}$ sequestration with an oxygen-fired combustion plant can be performed in a proven reliable technology while maintaining a low-cost high-efficiency power 
plant. As new lower power-consuming air separation techniques, such as membrane separation, become commercially available for large scale operation in $\mathrm{O}_{2}$-fired plants, the $\mathrm{CO}_{2}$ removal power consumption and efficiency reduction will continue to decline.

This study will continue with the following subsequent tasks:

Task 3: Combustion System Design and Analysis

Task 4: Furnace and HRA Design and Analysis

Task 5: Cost Estimate 


\subsection{References}

1. White, J.S., Buchanan, T.L., Schoff, R.L. (Parsons); Stiegel, G. (DOE); Holt, N.A., Booras G. (EPRI); Wolk, R. (WITS), "Evaluation of Innovative Fossil Fuel Power Plants with $\mathrm{CO}_{2}$ Removal”, EPRI Report No. 1000316, December 2000.

2. Wilkinson, M.,Boden, John (BP), Panesar, R. (Mitsui Babcock), Allam, R. (Air Products), " $\mathrm{CO}_{2}$ Capture Via Oxygen Firing: Optimisation of a Retrofit Design Concept for a Refinery Power Station Boiler", First National Conference on Carbon Sequestration, May 15-17, 2001, Washington DC. 


\subsection{Bibliography}

N/A 


\subsection{List of Acronyms and Abbreviations}

$\begin{array}{ll}\text { A } & \text { Absorptivity } \\ \varepsilon & \text { Emissivity } \\ \sigma & \text { Stefan-Boltzmann constant } \\ \text { ASU } & \text { Air separation unit } \\ \text { CFD } & \text { Computational fluid dynamics } \\ \text { FD } & \text { Forced draft } \\ \text { FGD } & \text { Flue gas de-sulfurization reactor } \\ \text { HHV } & \text { Higher heating value } \\ \text { HRA } & \text { Heat recovery area } \\ \text { ID } & \text { Induced draft } \\ \text { IGCC } & \text { Integrated gasification combined cycle } \\ \text { LHV } & \text { Lower heating value } \\ \text { NGCC } & \text { Natural gas combined cycle } \\ \text { NOx } & \text { Nitrogen oxides } \\ \text { PC } & \text { Pulverized coal } \\ \text { Q/A } & \text { Heat Flux } \\ \text { SCR } & \text { Selective catalytic reactor } \\ \text { T } & \text { Temperature } \\ \text { TEG } & \text { Triethyleneglycol } \\ \text { U } & \text { Heat transfer coefficient } \\ \text { UBC } & \text { Unburned carbon loss }\end{array}$

